NASA/TM-2010-216352

AIAA-2009-4578

\title{
Lunar Surface Stirling Power Systems Using Isotope Heat Sources
}

Paul C. Schmitz

Power Computing Solutions, Inc., Avon, Ohio

L. Barry Penswick

Sest, Inc., Middleburg Heights, Ohio

Richard K. Shaltens

Glenn Research Center, Cleveland, Ohio 


\section{NASA STI Program . . . in Profile}

Since its founding, NASA has been dedicated to the advancement of aeronautics and space science. The NASA Scientific and Technical Information (STI) program plays a key part in helping NASA maintain this important role.

The NASA STI Program operates under the auspices of the Agency Chief Information Officer. It collects, organizes, provides for archiving, and disseminates NASA's STI. The NASA STI program provides access to the NASA Aeronautics and Space Database and its public interface, the NASA Technical Reports Server, thus providing one of the largest collections of aeronautical and space science STI in the world. Results are published in both non-NASA channels and by NASA in the NASA STI Report Series, which includes the following report types:

- TECHNICAL PUBLICATION. Reports of completed research or a major significant phase of research that present the results of NASA programs and include extensive data or theoretical analysis. Includes compilations of significant scientific and technical data and information deemed to be of continuing reference value. NASA counterpart of peer-reviewed formal professional papers but has less stringent limitations on manuscript length and extent of graphic presentations.

- TECHNICAL MEMORANDUM. Scientific and technical findings that are preliminary or of specialized interest, e.g., quick release reports, working papers, and bibliographies that contain minimal annotation. Does not contain extensive analysis.

- CONTRACTOR REPORT. Scientific and technical findings by NASA-sponsored contractors and grantees.
- CONFERENCE PUBLICATION. Collected papers from scientific and technical conferences, symposia, seminars, or other meetings sponsored or cosponsored by NASA.

- SPECIAL PUBLICATION. Scientific, technical, or historical information from NASA programs, projects, and missions, often concerned with subjects having substantial public interest.

- TECHNICAL TRANSLATION. Englishlanguage translations of foreign scientific and technical material pertinent to NASA's mission.

Specialized services also include creating custom thesauri, building customized databases, organizing and publishing research results.

For more information about the NASA STI program, see the following:

- Access the NASA STI program home page at http://www.sti.nasa.gov

- E-mail your question via the Internet to help@ sti.nasa.gov

- Fax your question to the NASA STI Help Desk at $443-757-5803$

- Telephone the NASA STI Help Desk at 443-757-5802

- Write to: NASA Center for AeroSpace Information (CASI) 7115 Standard Drive Hanover, MD 21076-1320 
NASA/TM-2010-216352

AIAA-2009-4578

Lunar Surface Stirling Power Systems Using Isotope Heat Sources

Paul C. Schmitz

Power Computing Solutions, Inc., Avon, Ohio

L. Barry Penswick

Sest, Inc., Middleburg Heights, Ohio

Richard K. Shaltens

Glenn Research Center, Cleveland, Ohio

Prepared for the

Seventh International Energy Conversion Engineering Conference (IECEC)

sponsored by the American Institute of Aeronautics and Astronautics

Denver, Colorado, August 2-5, 2009

National Aeronautics and

Space Administration

Glenn Research Center

Cleveland, Ohio 44135 


\section{Acknowledgments}

The work described in this paper was performed for the Exploration Systems Mission Directorate (ESMD), which provided funding for these projects.

Level of Review: This material has been technically reviewed by technical management.

Available from

NASA Center for Aerospace Information

7115 Standard Drive

Hanover, MD 21076-1320
National Technical Information Service 5301 Shawnee Road Alexandria, VA 22312

Available electronically at http://gltrs.grc.nasa.gov 


\title{
Lunar Surface Stirling Power Systems Using Isotope Heat Sources
}

\author{
Paul C. Schmitz \\ Power Computing Solutions, Inc. \\ Avon, Ohio 44011 \\ L. Barry Penswick \\ Sest, Inc. \\ Middleburg Heights, Ohio 44130 \\ Richard K. Shaltens \\ National Aeronautics and Space Administration \\ Glenn Research Center \\ Cleveland, Ohio 44135
}

\begin{abstract}
For many years, NASA has used the $\alpha$ decay of plutonium-238 (Pu-238) (in the form of the General Purpose Heat Source (GPHS)) as a heat source for Radioisotope Thermoelectric Generators (RTGs), which have provided electrical power for many NASA missions. While RTGs have an impressive reliability record for the missions in which they have been used, their relatively low thermal to electric conversion efficiency and the scarcity of plutonium-238 (Pu-238) has led NASA to consider other power conversion technologies. NASA is considering returning both robotic and human missions to the lunar surface and, because of the long lunar nights (14.75 Earth days), isotope power systems are an attractive candidate to generate electrical power. NASA is currently developing the Advanced Stirling Radioisotope Generator (ASRG) as a candidate higher efficiency power system that produces greater than $160 \mathrm{~W}$ with two GPHS modules at the beginning of life (BOL) ( $\sim 32 \%$ efficiency). The ASRG uses the same Pu-238 GPHS modules, which are used in RTG, but by coupling them to a Stirling convertor provides a four-fold reduction in the number of GPHS modules. This study considers the use of americium-241 (Am-241) as a substitute for the Pu-238 in Stirlingconvertor-based Radioisotope Power Systems (RPS) for power levels from tens of W to $5 \mathrm{kWe}$. The Am-241 is used as a substitute for the Pu-238 in GPHS modules. Depending on power level, different Stirling heat input and removal systems are modeled. It was found that substituting Am-241 GPHS modules into the ASRG reduces power output by about one-fifth while maintaining approximately the same system mass. In order to obtain the nominal $160 \mathrm{~W}$ of electrical output of the Pu-238 ASRG requires $10 \mathrm{Am}-241$ GPHS modules. Higher power systems require changing from conductive coupling heat input and removal from the Stirling convertor to either pumped loops or heat pipes. Liquid metal pumped loops are considered as the primary heat transportation on the hot end and water pumped loop/heat pipe radiator is considered for the heat rejection side for power levels above $1 \mathrm{kWe}$.
\end{abstract}

\section{Nomenclature}

$\begin{array}{ll}\text { GPHS } & \text { General Purpose Heat Source } \\ \text { MLI } & \text { multi-layer insulation } \\ \text { RPS } & \text { Radioisotope Power Systems } \\ \text { RTG } & \text { Radioisotope Thermoelectric Generator } \\ \text { FeNdB } & \text { iron neodymium boron } \\ \text { SmCo } & \text { samarium cobalt } \\ \text { ASRG } & \text { advanced Stirling radioisotope generator } \\ \text { BOL } & \text { Beginning-of-Life }\end{array}$




$\begin{array}{ll}\text { EOL } & \text { End-of-Life } \\ \text { DOE } & \text { Department of Energy } \\ \text { Mar-M247 } & \text { super alloy } \\ \text { SOA } & \text { State-of-the-Art } \\ \text { LM } & \text { Lockheed Martin Corp. }\end{array}$

\section{Introduction}

NASA is currently studying both manned and unmanned missions to the lunar surface. The lunar surface is a challenging environment for power systems due to its wide fluctuations in temperature and its long nighttime period (29.5 earth day/night cycle). Because of these very long night periods, any solararray-based system must have an energy storage system that provides power during this 14.75-day period. Isotope power systems offer an attractive alternative because of their relatively constant power output over the lunar day/night cycle. Although plutonium-238 (Pu-238) has many attractive features, it is possible to use other isotopic heat sources with Stirling convertors to generate electrical power. This study considered replacing the Pu-238 in the General Purpose Heat Source (GPHS) with americium-241 (Am-241) and then conceptually integrating these new heat sources with Stirling convertors. Strontium90 (Sr-90) is also considered for the Advanced Stirling Radioisotope Generator (ASRG) to show the effect on power output due to the relatively short half-life of the Sr-90.

\section{Isotope Candidates}

The GPHS has been used for many deep space missions when there is a lack of adequate solar illumination to power solar cells (Ref. 1). It is a Department of Energy (DOE) standardized thermal source that produces approximately $250 \mathrm{~W}$ of thermal power at the beginning of life (BOL). Dimensions of a GPHS module are shown in Table 1 (Ref. 2).

TABLE 1.-GPHS DIMENSIONS
\begin{tabular}{|l|c|}
\hline Height & $5.92 \mathrm{~cm}$ \\
\hline Width & $9.32 \mathrm{~cm}$ \\
\hline Length & $9.95 \mathrm{~cm}$ \\
\hline
\end{tabular}

$\mathrm{PuO}_{2}$ is the molecule of $\mathrm{Pu}-238$ that is used as the fuel for the GPHS. $\mathrm{PuO}_{2}$ is placed in four iridium capsules and surrounded by a graphite shell to form each GPHS module (Refs. 3 to 6). Figure 1 shows a drawing of a GPHS. Pu-238 is attractive because most of its radioactive decay energy comes from an alpha emission and it has a long half-life $(87 \mathrm{yr})$. Relatively low amounts of neutron emission come from both spontaneous fission and $(\alpha, n)$ reactions, which result from the interactions of the high energy alpha particles with low atomic mass materials. The iridium capsule prevents the alpha particles from leaving the fuel pellet (and interact with the surrounding graphite) but interactions with both $\mathrm{O}_{17}$ and $\mathrm{O}_{18}$ in the $\mathrm{PuO}_{2}$ mixture does produce some neutron flux. Production of $\mathrm{Pu}-238$ is commonly done by neutron irradiation of neptunium-237 (Np-237) in a high-flux reactor. The product of this irradiation is Np-238 that decays (2.117 day half-life) via beta emission into $\mathrm{Pu}-238$. Currently we buy our $\mathrm{Pu}-238$ from the Russians when used with the GPHS-RTG (Radioisotope Thermoelectric Generator) systems.

Because of the scarcity of Pu-238 (Ref. 7) other candidates have been considered (Ref. 8). Reference 6 outlines the expected power output, mass, and other physical characteristics when different isotopes replace the $\mathrm{PuO}_{2}$ in GPHS modules. Although there are many possible isotope replacements, Am-241 and Sr-90 are two candidates each with greater availability than Pu-238. Notable differences between the three isotopes are half-life, power density, and radiation emission. Am-241 has a specific power that is about one-fifth that of Pu-238 while its half-life is about 5 times as great (87.5 vs. $433 \mathrm{yr}$ ). Both Pu-238 and Am-241 produce relatively flat power profiles over the assumed 10-yr 


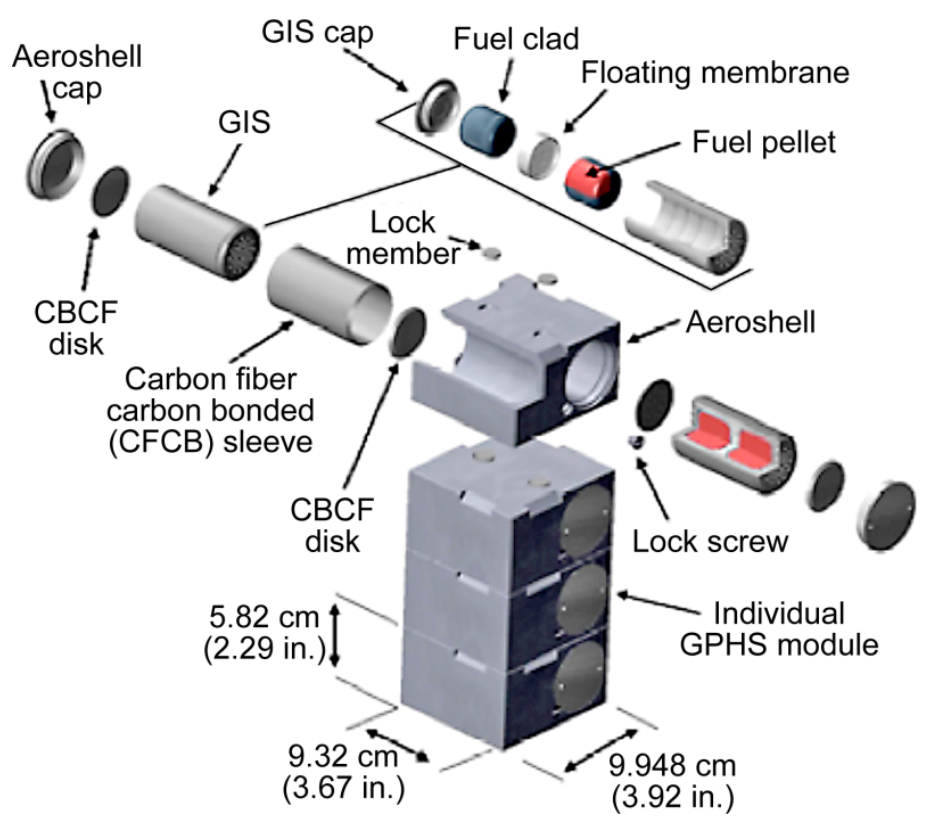

Figure 1.-GPHS Module.

mission. Am-241 does have a gamma emission with photon energy of $59.5 \mathrm{KeV}$ that can be easily shielded. Am-241 is produced from transuranic waste and is readily available.

$\mathrm{Sr}-90$ is not practical as a direct substitute for $\mathrm{Pu}-238$ without additional shielding due to the emission of secondary gamma rays ( $2 \mathrm{MeV}$ from the yttrium-90 (Y-90)) and the short-lived daughter nuclei from the beta decay of Sr-90. Additionally, Sr-90 with its relatively short half-life when compared with $\mathrm{Pu}-238$ or Am-241 loses approximately one-third of its thermal output over the 10-yr mission life used in this study.

Many different molecules can be made from the isotopes considered above. In this study GPHS performance is estimated with Am-241 in the form of $\mathrm{AmO}_{2}$ and $\mathrm{Sr}-90$ in the form of SrO. Other possible candidates can be found in Reference 9 . Table 2 provides a summary of the isotope candidates.

Figure 2 shows the heat output as a function of time for a GPHS module filled with the isotopic compounds $\mathrm{PuO}_{2}, \mathrm{AmO}_{2}$, and $\mathrm{SrO}$. Sr-90 has a much higher specific power (W/g) but its lower density combined with the volume available in the GPHS module limits the thermal output. SrO and $\mathrm{AmO}_{2}$ when placed in GPHS modules have very similar power outputs of 42.8 and $56.9 \mathrm{~W}$, respectively. Because of their similar thermal power outputs and $\mathrm{AmO}_{2}$ lower gamma radiation, $\mathrm{Am}-241$ is selected as the isotope for further study. A brief analysis using Sr-90 is provided to show some of the difficulties in integrating a power source where its half-life becomes a significant fraction of the operational life of the system. For this analysis heater head temperatures were limited to $1123 \mathrm{~K}$, which is consistent with the current State-of-the-Art MarM247 super alloy currently being used in the ASRG. All of the isotope compounds considered here have melting points well above this limit and should have no impact on the selection criteria.

TABLE 2.-ALTERNATIVE ISOTOPES SUMMARY

\begin{tabular}{|l|l|c|c|c|c|c|c|}
\hline Isotope & $\begin{array}{c}\text { Compound } \\
\text { form }\end{array}$ & $\begin{array}{c}\text { Half-life, } \\
\mathrm{yr}\end{array}$ & $\begin{array}{c}\text { Melting } \\
\text { temperature, } \\
\mathrm{K}\end{array}$ & $\begin{array}{c}\mathrm{W} \text { per cc, } \\
\mathrm{W} / \mathrm{cm}^{3}\end{array}$ & $\begin{array}{c}\mathrm{W} \text { per, } \\
\mathrm{g}\end{array}$ & $\begin{array}{c}\text { Class of } \\
\text { emitter }\end{array}$ & $\begin{array}{c}\text { Heat generated } \\
\text { BOL, } \\
\mathrm{W}\end{array}$ \\
\hline $\mathrm{Pu}-238$ & $\mathrm{PuO}_{2}$ & 87.7 & 2673 & 3.9 & 0.39 & $\alpha$ & 250 \\
\hline $\mathrm{Am}-241$ & $\mathrm{AmO}_{2}$ & 432.7 & 2273 & 0.088 & 0.097 & $\alpha$ & ${ }^{\mathrm{a}} 56.9$ \\
\hline $\mathrm{Sr}-90$ & $\mathrm{SrO}$ & 28.8 & 1661 & 0.66 & 0.128 & $\beta$ & ${ }^{\mathrm{a}} 42.8$ \\
\hline
\end{tabular}

${ }^{\mathrm{a} B}$ Based on keeping iridium capsule volume constant and filling with isotopic compound. 


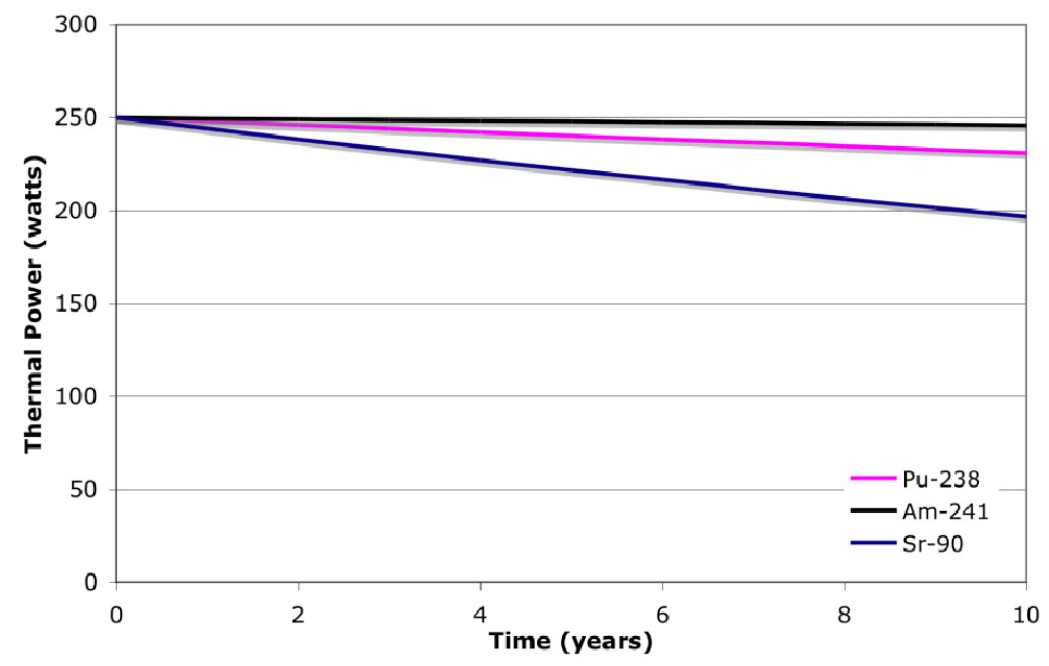

Figure 2.-Thermal power output of a GPHS with various isotopes.

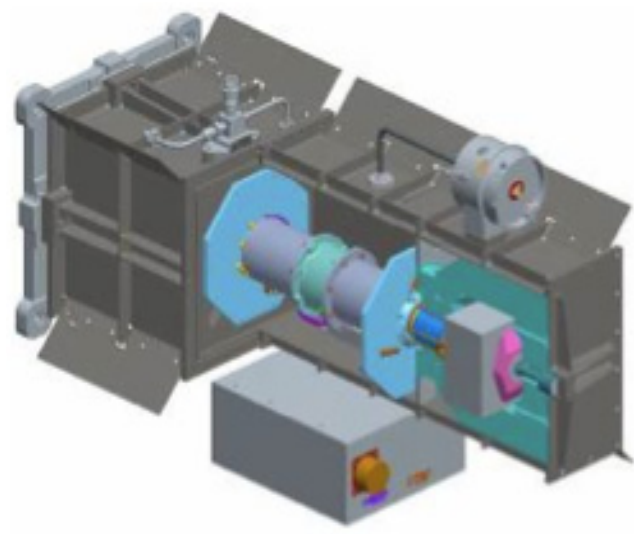

Figure 3.-ASRG.

\section{System Layout}

In the ASRG, the GPHS modules are placed at the two ends of the ASRG and the heat is conductively coupled into the heater head of the Stirling convertor (see Fig. 3). Heat is removed via a solid conductor from the cold end of the Stirling out to the housing/radiator surface. As electrical power requirements grow, additional heat and GPHS modules are required. For heat input, one-way to arrange the additional GPHS modules is to circle the Stirling convertor heater head (see Fig. 4 and more detailed discussion in the Stirling Convertors section of this paper). Conductive coupling is practical until the resistive losses and mass of the conductive interface become prohibitive. For this study, the maximum number of GPHS modules for conductive coupling was limited to six per Stirling convertor.

For power levels when conductive coupling is no longer practical, a pumped loop is used to transport heat to and from the Stirling convertor. On the hot side, NaK is pumped over a GPHS to a NaK heat exchanger and then to the Stirling convertor using an electromagnetic pump. Heat is removed via a flowing water loop. Notable differences between the Pu-238 and the Sr-90 and Am-241 are the number of GPHS modules required to produce any specific power level and its decay profile. Table 3 shows the method of heat transport as a function of the number of GPHS modules and isotope. 


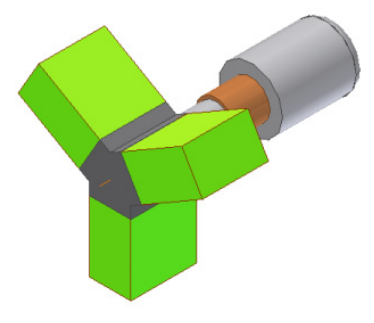

Figure 4.-A three GPHS module/ convertor configuration.

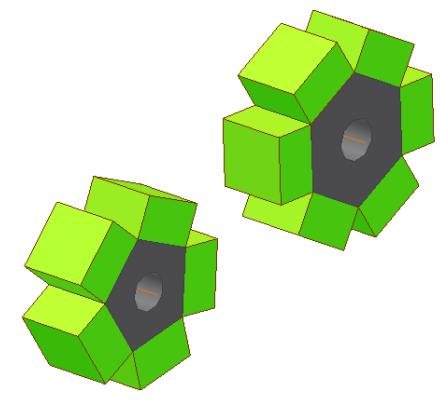

Figure 5.-Five and six GPHS geometries for a SRG.

TABLE 3.-HEAT SOURCE AND HEAT REJECTION INTERFACE METHOD

\begin{tabular}{|l|c|c|c|c|c|c|}
\hline \multicolumn{1}{|c|}{$\begin{array}{c}\text { Number of GPHS } \\
\text { Modules per convertor }\end{array}$} & \multicolumn{2}{|c|}{1} & \multicolumn{2}{c|}{2 to 6} & \multicolumn{2}{c|}{$>6$} \\
\hline \multirow{2}{*}{ Power level, W } & Pu-238 & $\begin{array}{c}\text { Am-241/ } \\
\text { Sr-90 }\end{array}$ & Pu-238 & Am-241 & Pu-238 & Am-241 \\
\cline { 2 - 7 } & 160 & $\sim 20$ & $\begin{array}{c}\sim 300 \text { to } \\
1000\end{array}$ & 60 to 240 & $>1120$ & $>210$ \\
\hline $\begin{array}{l}\text { GPHS to Stirling } \\
\text { interface }\end{array}$ & Cond & Cond & Cond & Cond & PL & PL \\
\hline $\begin{array}{l}\text { Stirling to radiator } \\
\text { interface }\end{array}$ & Cond & Cond & HP or PL & Cond & PL & PL \\
\hline
\end{tabular}

Cond $=$ Conductive Coupling

$\mathrm{HP}=$ Heat Pipe Heat Transport

$\mathrm{PL}=$ Pumped Loop

\section{GPHS to Stirling Coupling}

\section{Conductive Coupling}

The ASRG GPHS module is located forward of the heater head and coupled to it via a "hot shoe" that acts as the thermal interface between the two components (Ref. 10). The heat transfer mechanism is used solely via conduction through the hot shoe material that is generally a nickel-200 (Ni-200) series alloy because of their relatively high thermal conductivity.

Conductive coupling is practical provided the heat flux and distance between the GPHS and Stirling is not too great. Figure 5 shows that as the number of GPHS modules grows, the distance from the surface of the GPHS module to the heater head must also grow. This additional distance and its associated temperature drops and the mass of the conductive plate and insulation eventually make a conduction coupling prohibitive.

\section{Pumped Loop Integration of Heat Source}

For Pu-238 with pumped loop heat transport systems, three power levels $(1,2$, and $5 \mathrm{kWe})$ were modeled using both $\mathrm{Pu}-238$ and Am-241. Figure 6 shows the fundamental component layout for this system (Ref. 11).

The proposed conceptual LM heat exchanger, shown in Figure 7, is configured to take advantage of the relatively low heat flux levels produced by the alternative isotope GPHS modules. The modules are clamped against a flat plate Heat Exchanger through which the LM flows. The internal LM flow passage geometry is optimized via the passages formed in a machined plate that is brazed between to the exterior face sheets that are in contact with the GPHS modules. It is important to note that the GPHS modules are not exposed to the LM flow and as such the potential venting/out gassing of the GPHS module cannot 


\section{GPHS Modules / Flat LM HX Assembly}

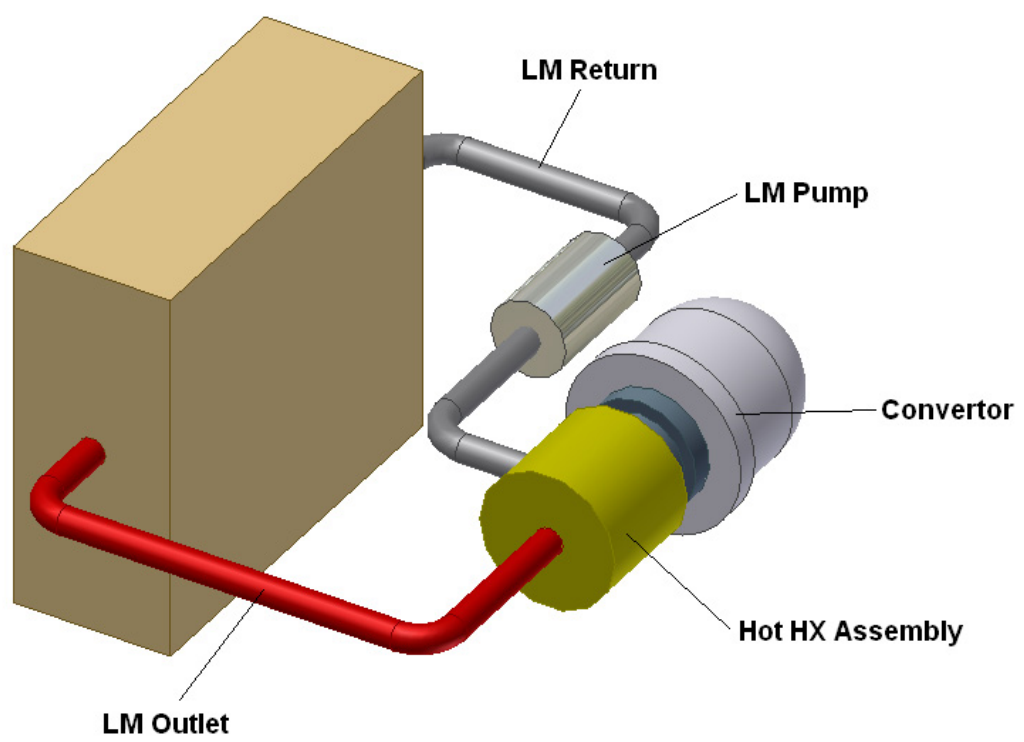

Figure 6.-Pumped loop heat transport system configuration.

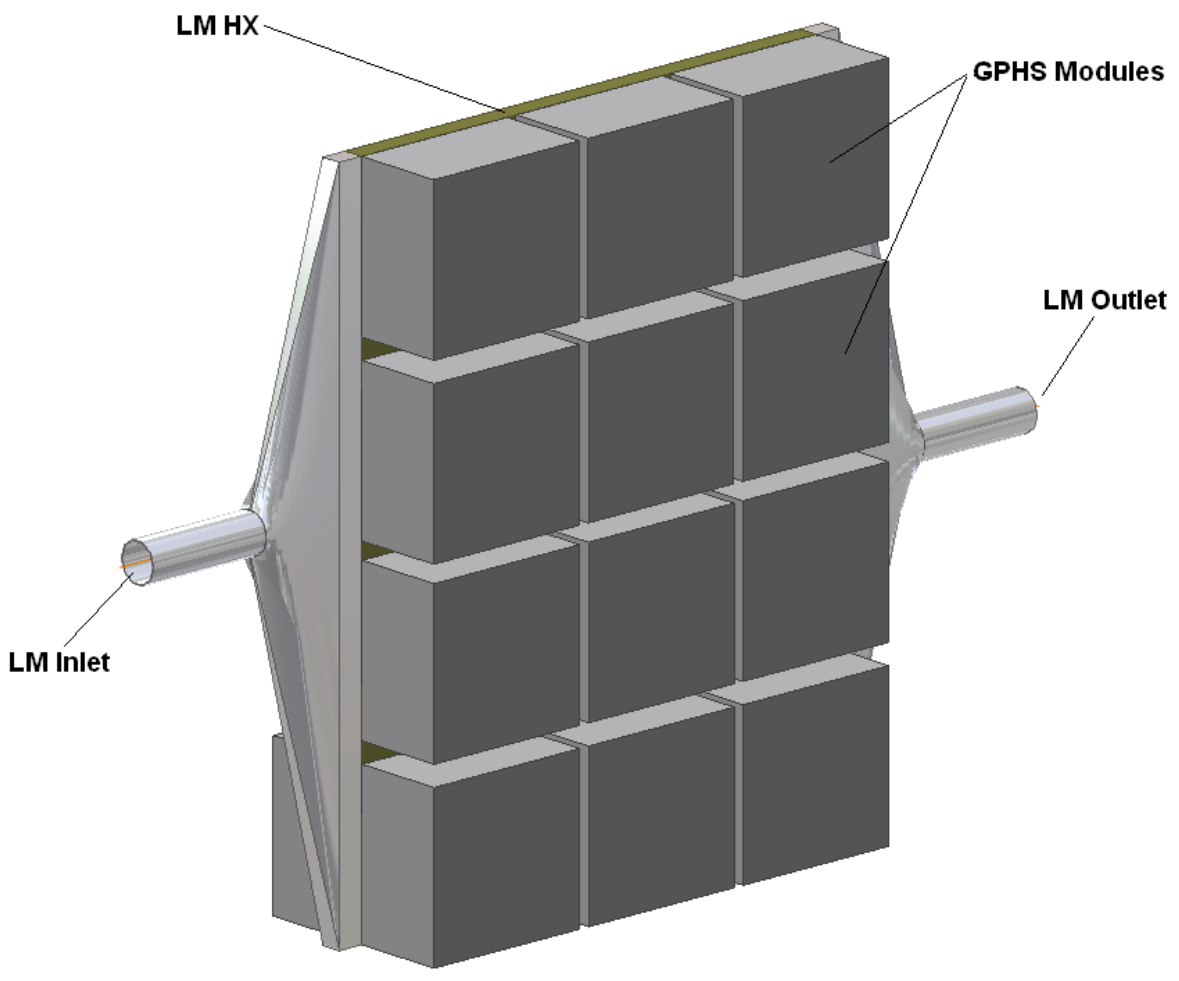

Figure 7.-GPHS module/LM HX configuration. 
contaminate the LM flow circuit. Since the structural loads are relatively low, the materials in contact with the LM working fluid can be fabricated from fully compatible materials such as stainless steel-316 (SS-316). In higher stressed areas this compatible material can be clad to the desired higher strength materials such as Ni-based superalloys.

At the interface with the convertor hot-end HX, the LM working fluid would flow through passages configured to ensure the proper heat transfer between the fluid and the Stirling convertor HX wall. A number of configurations for the LM HX are available ranging from a simple annular flow passage to more complex flow geometries. An important aspect in the implementation of either of these configurations is the design of the LM manifold system, which must ensure that the LM flow is uniform within the core of the HX while also minimizing the pump power required due to the HX pressure drop.

\section{Stirling Convertors}

A "family" of Stirling convertors was used in the evaluation of the Lunar Power System (LPS). These were derived directly from either existing hardware (in the case of the ASRG and $1 \mathrm{~kW}$ ), operating existing hardware well off their nominal operating point (the low power ASRG), or defined via well proven scaling rules for Stirling convertors using the latter hardware as a baseline. For example, scaling to a very low power convertor and to the $2-$ and $5-\mathrm{kW}$ high-power variants. Utilizing this approach it is a straightforward matter to scale this technology to different power levels and waste heat rejection temperatures, which will allow the convertors to be evaluated within the overall LPS context. The following material discusses a number of technical aspects of these convertors, various operating constraints, and potential changes required for a LPS application.

The convertor technology utilized in the LPS evaluation is derived from that employed in the Advanced Stirling Convertor (ASC) currently under joint development by the industry team of Sunpower, Inc., LM, and NASA GRC. This convertor and the associated technology emphasizes the use of high heater head temperatures $\left(1123 \mathrm{~K}\left(850^{\circ} \mathrm{C}\right)\right.$ versus the current widely employed $\left.923 \mathrm{~K}\left(650^{\circ} \mathrm{C}\right)\right)$ (Ref. 12), high specific power levels ( 75 to $100 \mathrm{We} / \mathrm{kg}$ ), and electrical output to thermal input efficiencies of approximately 60 percent of Carnot producing on the order of $160 \mathrm{~W}$ of electrical power when incorporating two standard Pu-238-fueled GPHS modules.

The existing ASRG hardware was considered for application directly into two systems that employed a varying number of GPHS modules with the alternative isotope. The first technique was to approach or meet the current power output of the ASRG via the use of a large number of Am-241 GPHS modules coupled to a modified ASRG heater head, as shown schematically in Figure 5. The other option was to employ a single modified Am-241 GPHS to a single ASRG convertor heat collector. In this case the output power would be about $1 / 5$ of an ASRG convertor using Pu-238. While this latter approach dramatically reduced program risk, the performance of the convertor system is significantly lower than the nominal values of the current ASRG. This is due to the fact that in the small, low-power convertors, the parasitic thermal losses through the mechanical hardware itself can be significant. This occurs independent of the operating power level of the convertor.

The alternative is to simply "scale" the current ASRG design to a lower power level where the parasitic losses are resolved. However, in some cases it may not be possible to totally eliminate these size-related effects for reasons such as manufacturing limits that define minimum allowable wall thickness, which are above those desired. These various technical issues were incorporated into the scaling techniques and provide a relationship considering desired power level and convertor operating temperatures versus convertor efficiency, as shown in Figure 8, where the reference value (1.0) is on the order of $90 \mathrm{~W}$. These relationships were used in the LPS evaluation process.

An additional issue that must be considered for the conductively coupled configurations discussed above is heat flux capabilities of the alternative isotopes. The temperature limits for the GPHS modules are set by iridium alloy capsule cladding placed around the Pu- 238 fuel. Using the largest face ( 9.32 by $9.72 \mathrm{~cm}$ ), the maximum heat flux out of a single GPHS module at BOL with insulation on the other sides 


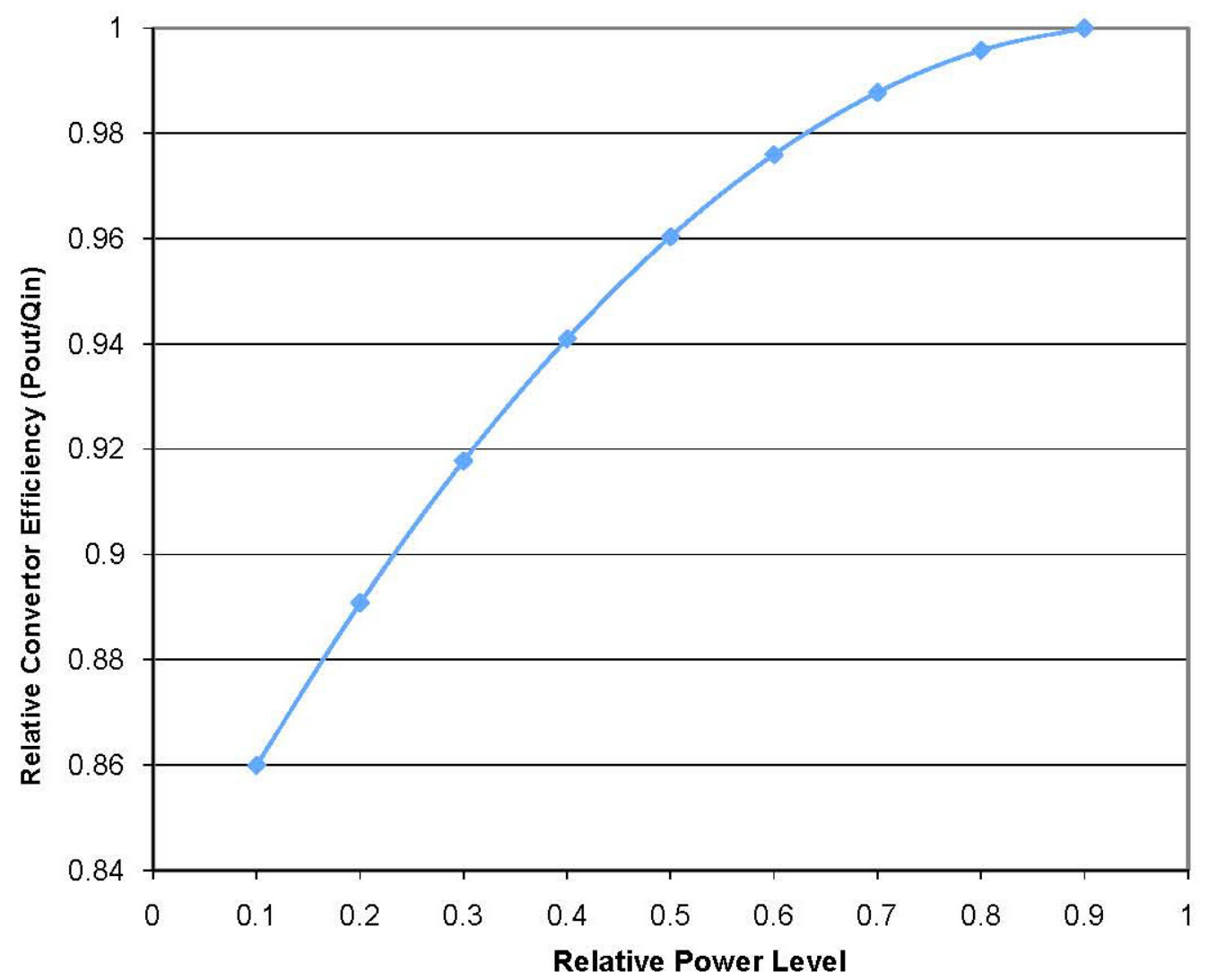

Figure 8.--Impact of convertor power level on conversion efficiency.

is $2.69 \mathrm{~W} / \mathrm{cm}^{2}$ using Pu-238 fuel (Ref. 13). This drops to $0.61 \mathrm{~W} / \mathrm{cm}^{2}$ for Am-241 and $0.46 \mathrm{~W} / \mathrm{cm}^{2}$ for Sr-90. In contrast to the low heat flux from the GPHS modules is that of the Stirling convertor heater head, which requires an input heat flux of about 12 to $15 \mathrm{~W} / \mathrm{cm}^{2}$. It was shown with $>6$ GPHS modules conductively coupling GPHS to Stirling convertors became mass prohibitive (Ref. 14). Because of the lower heat flux of both the Am-241 and Sr-90 systems, this has significant impact on the potential power levels for the conductively coupled configurations.

With the introduction of the pumped loop heat transport mechanism using a LM working fluid, the issues of the thermal "coupling" between the convertor's hot-end heat exchanger and the isotope heat sources change dramatically for the higher power convertors evaluated within LPS. With this HTS configuration the LM side HX characteristics can be tailored to those of the convertor's helium heat exchange process resulting in a highly effective overall heat transfer process.

For higher power levels, two evaluation paths were considered. One option for the evaluation of the 1-KWe class of power convertors employing a pumped liquid metal loop was utilizing a well-defined 1-KWe Sun Power, Inc., (shown in Fig. 9) convertor as a reference point. This specific convertor is of a very robust design developed initially for residential micro co-generation applications and operates at hotend temperatures in the range of 775 to $825 \mathrm{~K}$. All of the fundamental convertor technology employed such as the linear alternator design, piston/displacer assembly, gas bearing system, etc., are exactly the same as those that would be employed in a high-power space-based design and are currently used in the ASRC convertor. This convertor has been modified to incorporate a pumped LM hot-end heat exchanger, as shown in the following photograph, and currently is installed in a LM pumped loop test facility located at Marshall Space Flight Center (MSFC). Testing is expected to commence in the June 2009 time period. The primary goal of this testing to fully define the operating and performance characteristics of the LM heated version to those of the well-defined 1-kW engine. The latter has been tested extensively at NASA 
GRC under well-controlled conditions. As can be seen in the photograph, the only change to the basic convertor is the

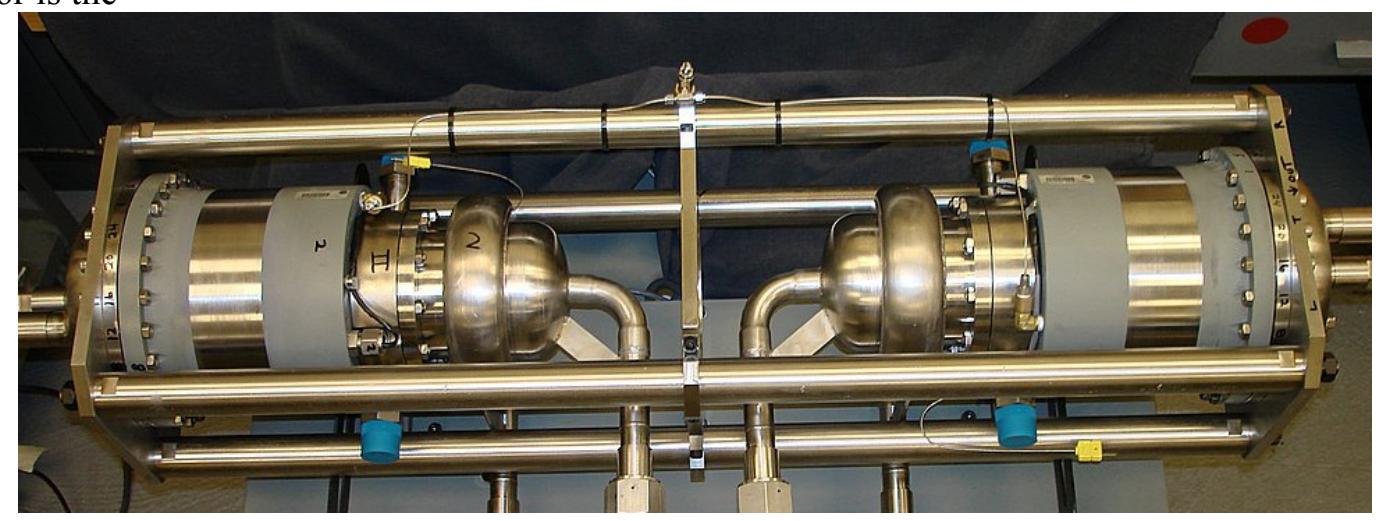

Figure 9.-1-kWe convertor modified for use with LM pumps.

addition of the sheet metal (SS-316) inlet/outlet manifold that directs the LM over the existing convertor heater head. This same basic configuration would be employed in the alternative isotope-based system. Because of the design goals for the basic convertor, the unit is heavier and has lower performance than desired for the LPS.

While the above configuration represents one approach, the primary approach employed in the LPS evaluation was to scale up in power utilizing the higher hot-end material capabilities demonstrated as in the ASRG convertor. This scale up process is actually easier to carry out since the majority of the issues discussed above that occur in scaling to lower powers are eliminated. For the specific convertors considered, it was assumed that the Mar-M-247 material technology would be applied. Because of potential interactions between this material and the LM working fluid, it was assumed that a compatible material, such as SS-316, was clad to the LM exposed surfaces. This cladding does not provide any structural support. Because of the high operating temperature capability of this material, it is possible to retain conventional cycle temperature ratios but also provide higher rejection temperatures that greatly assist in the radiator sizing. Based on these scaling rules, a set of performance relationships were developed, which coupled the output power level and hot-end operating temperatures to the convertor efficiency. The specific power of the Stirling convertor itself improves somewhat with power level; however, this change is relatively small in comparison to the significant mass changes that occur in the convertor-related subsystems involving the multiple GPHS to convertor integration and waste heat radiator (Ref. 15). Therefore, the focus of the convertor evaluation was in the areas of integration with the GPHS heat source, vibration isolation options, and convertor impact on LPS configurations.

One issue that must be considered is that of all the "reference" convertor configurations discussed above, the linear alternators employ high-performance FeNdB magnet technology. Due to this magnet's operating temperature limits, the convertor's rejection temperature is constrained to less than approximately 390 to $400 \mathrm{~K}\left(115\right.$ to $\left.125^{\circ} \mathrm{C}\right)$. In many of the cases considered the worst-case lunar sink temperature is $340 \mathrm{~K}\left(67^{\circ} \mathrm{C}\right)$ allowing only a $50 \mathrm{~K}$ temperature difference between the cold end and sink temperature to reject heat. In order to allow adequate margin and to maintain a reasonable size on radiator area, samarium cobalt ( $\mathrm{SmCo}$ ) magnets were used for all convertors modeled. SmCo magnet/alternator technology limits rejection temperatures to somewhat less than $550 \mathrm{~K}\left(250^{\circ} \mathrm{C}\right)$ and in all cases the maximum Stirling cold-end temperature was set at $530 \mathrm{~K}$. Current assessment is that there is little impact on alternator mass and none on efficiency if SmCo magnets are used at temperatures between $400 \mathrm{~K}$ $\left(127^{\circ} \mathrm{C}\right)$ and $550 \mathrm{~K}\left(277^{\circ} \mathrm{C}\right)$ when compared with the FeNdB magnets operating at their lower temperature limits. 


\section{Heat Rejection}

The lunar surface provides a challenging environment for power systems operation due to the long duration of the lunar night and the large diurnal changes in environment temperature. At latitudes less than $85^{\circ}$, the lunar day/night cycle is relatively constant in duration and averages about 14.74 days ( $354 \mathrm{hr}$ ); at latitudes greater than $85^{\circ}$, the local terrain plays an important role in illumination.

Figure 10 shows the length of the lunar night as a function of latitude, from $0^{\circ}$ to $85^{\circ}$. During the day the lunar soil is a good solar absorber and emits its radiation back to the environment at temperatures near the operating temperature of the heat rejection radiators. Peak soil temperatures at the equator can reach over $370 \mathrm{~K}$ at local noon.

Sun position in the sky must also be known to calculate the direct insolation incident on the spacecraft components. To estimate the effects of these local environmental conditions on the RPS heat rejection system is assigned an orientation on the lunar surface. For the ASRG and other conductively coupled systems a cylinder is used to approximate the housing/radiator. These conductively coupled systems are oriented such that the piston motion is in line with the gravity vector. For the higher power systems, when the orientation of the radiator and the Stirling system is easily decoupled both vertical and horizontal radiators are considered. In the past, studies have analyzed the advantages and disadvantages of radiator orientation on the lunar surface (Refs. 16 and 17). From these studies, it was found that for vertically oriented radiators the maximum and minimum sink temperatures during the lunar day/night cycle was about 100 to $314 \mathrm{~K}$ and between 100 and $270 \mathrm{~K}$ for horizontal radiators that do not see the lunar surface. The trade between a two-sided radiator operating at a higher sink temperature and a single-sided radiator rejecting heat at a lower temperature may provide different answers depending on isotope availability or if the system is mass or area constrained. In addition, the large change in sink temperatures will result in changes in both the power output of the system and the temperature range requirements of the heat rejection system. For this study a vertical radiator is used, that is, a rectangular plane with one edge touching the lunar surface and the other edge skyward. Estimates of the surface and sky view factors on the radiator combined with their optical properties are used to generate an energy balance, which provide estimates of the radiator temperatures as a function of Sun location.

Additionally it is necessary to estimate the impacts of the lunar dust on the power system. Typically, solar emissivity/absorptivity for an orbiting platform treated with a high emissivity coating after a 10-yr life span in low Earth orbit (LEO) will be close to 0.9 and a thermal absorptivity of about 0.15 . Based on earlier work between Jet Propulsion Laboratory (JPL) and NASA GRC the thermal absorptivity of the radiator due to lunar soil contamination was estimated be at worst up to 0.5 with little change in solar emissivity (Ref. 18). Using these values for absorptivity and emissivity, effective sink temperatures can be found as a function of time of day. Figure 11 shows a plot of sink temperature as a function of time of day for a vertically oriented cylindrical radiator located at the equator. Peak sink temperature is about $340 \mathrm{~K}$ and occurs twice just before and after local noon and nighttime sink temperature of $100 \mathrm{~K}$. If the radiator dust contamination is not an issue and the thermal absorptivity is what we find in space then the peak temperature drops to $320 \mathrm{~K}$.

The most direct method of removing the waste heat from the Stirling convertor is to have a conductive coupling between the cooler section of the Stirling and a heat rejection surface. This method is used in the ASRG and consists of a cylindrical ring with the inner portion contacting the Stirling cooler and the outer surface of the ring in contact with the ASRG housing/radiator. The advantage of this configuration is obviously its simplicity. As the amount of heat rejected increases the trade between material thicknesses (and thus mass) an allowable temperature drop eventually favors other heat transport augmentation methods. Two other methods of heat removal are considered: heat pipes to move the waste heat from the Stirling cold end to the radiator surface and to flow a liquid over the cold end of the Stirling and pumping it to a radiator.

In this analysis, heat pipes are used either as the primary heat transport device from the Stirling cold end to the surface of a radiator or as a heat spreader connected the liquid pumped loop on the evaporator side and to the radiator fins on the other. 


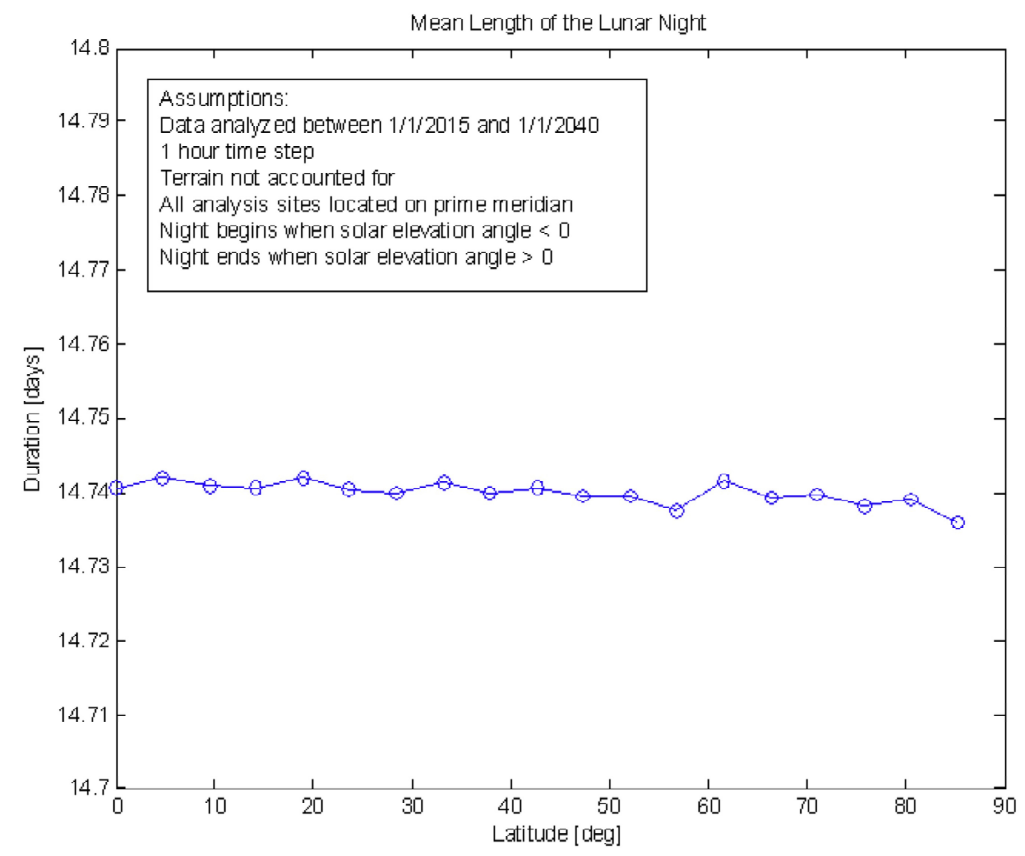

Figure 10.-Mean lunar night duration as a function of latitude.

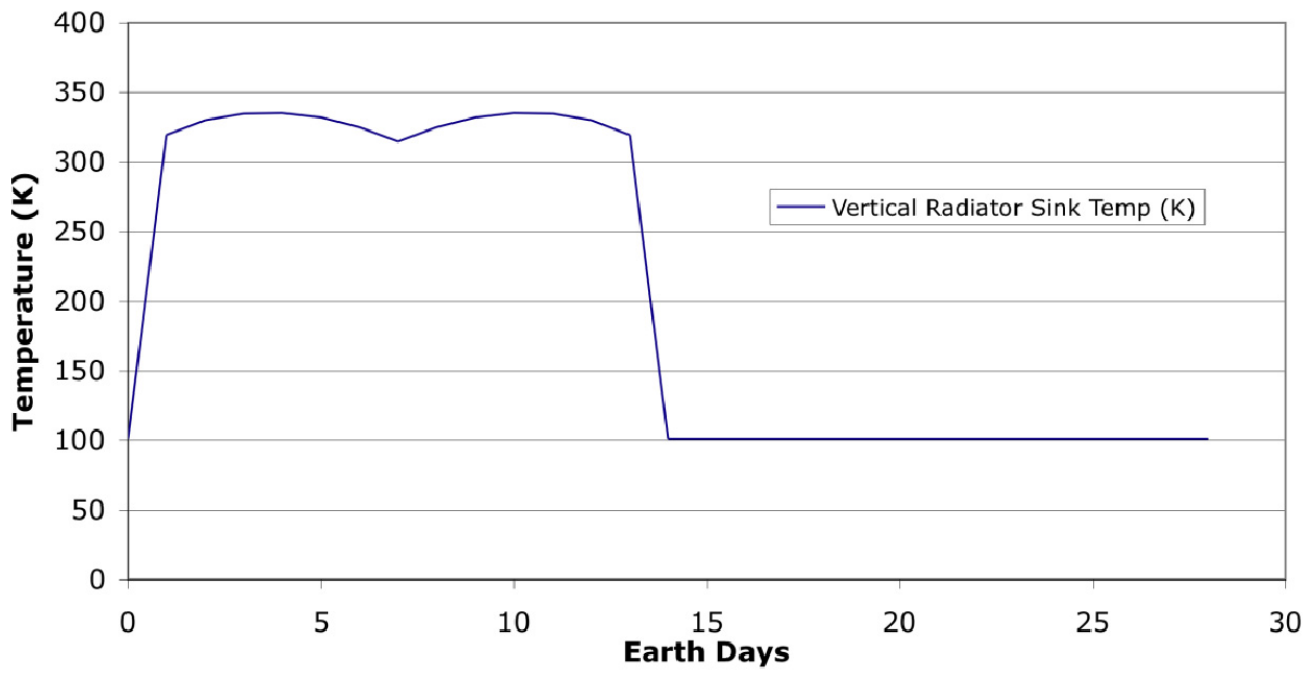

Figure 11.-Sink temperature as a function of time of lunar day. 


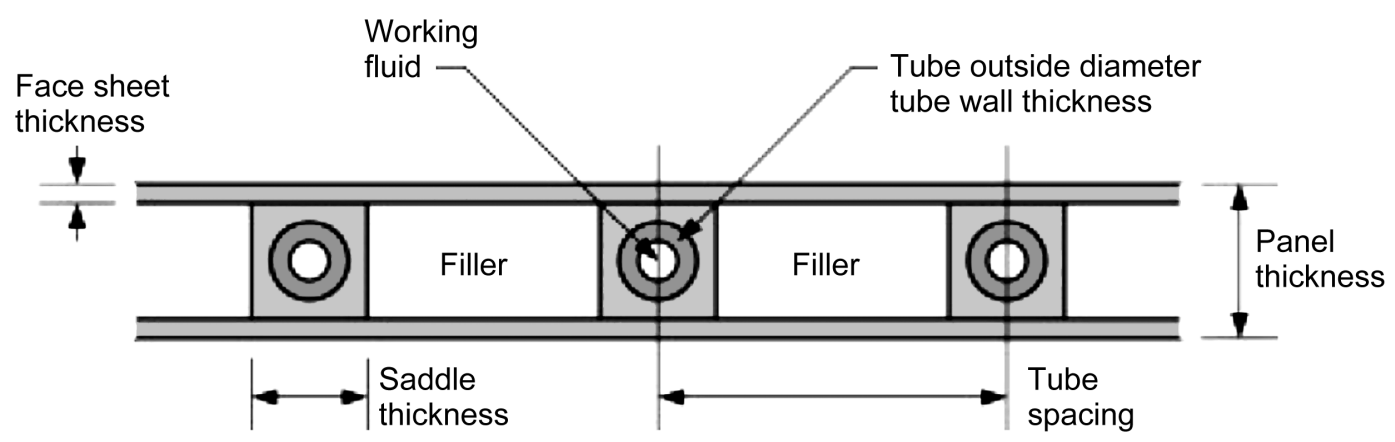

Figure 12.--Radiator panel layout.

For a pumped loop heat transport system, water is passed over the Stirling cold end, transported out to the radiator panels, goes through the pumps, and returns to the Stirling convertor. Stirling convertors operate best when the inlet to exit coolant temperature difference is kept to a minimum. In general the temperature rise of a fluid used to remove the waste heat should be about $25 \mathrm{~K}$ or less to ensure no Stirling cycle performance penalty. The radiator panel design, see Figure 12, consists of water heat pipes sandwiched between two outer face sheets. Panel mass was approximately $3.5 \mathrm{~kg} / \mathrm{m}^{2}$ for the cases shown for the two-sided radiator. This areal mass does not include the fluid ducts, fluid, or pumps, which are accounted for separately. The pump design selected is scaled from other space pumps and is scaled both in efficiency and mass to meet the pressure drop and flow rate requirements of the system.

\section{Analysis}

A modeling tool has been developed to size Stirling RPS systems that operate under a variety of environmental conditions and a wide range of power outputs. At each required power level cold-end temperature is varied to explore the trade between efficiency and mass. In order to minimize the amount of isotope required the thermodynamic cycle requires as low a waste heat rejection temperature as possible. The penalty for this low rejection temperature is that the area required to reject the waste heat increases with decreasing rejection temperature. This trade between the isotope source and radiator size leads to mass minimums for the overall system. After the design point is set, these component sizes are used to find off-design performance in both different environments and as the isotope decays in time.

\section{ASRG on the Lunar Surface}

The ASRG using Pu-238 is currently estimated to produce $\sim 160 \mathrm{~W}$ direct current (dc) when using the high-strength alloy MarM-247 as its heater head material and placed in a deep space environment (Ref. 19). Hot and cold side temperatures for the ASRG are $850(1123) / 90(363){ }^{\circ} \mathrm{C}(\mathrm{K})$, respectively. Each ASRG comprises two ASCs with each producing $88 \mathrm{~W}(2 \cdot 88=176 \mathrm{~W}$ total $)$ of alternating current (ac) power, which is sent through power conditioning and control electrics that monitor the ASRG and converts the $102-\mathrm{Hz}$ power to $28-\mathrm{V}$ dc (nominal). Estimates for the Power Conditioning and Control $(\mathrm{PC} \& \mathrm{C})$ at $164 \mathrm{~W}$ of throughput are estimated to be approximately $12 \mathrm{~W}$. Total dc power output for the ASRG under the above referenced conditions and with the $12 \mathrm{~W}$ for the PC\&C is $164 \mathrm{~W}$. Calculations are made as to how the ASRG would perform during both day/night cycles and over its required 10-yr life. Control of the ASRG is very important as to how the system will behave at off-nominal conditions. For these cases it was assumed the controller maintained a constant heater head temperature during the entire life of the mission. Other control schemes will be discussed later. Table 4 shows a summary of both the ASRG design point performance as quoted from NASA and estimates of how it will perform under the lunar environmental conditions. Power output during daylight hours falls from the nominal 164 (estimate) to $143 \mathrm{~W}$ due to the higher temperatures of the surrounding environment. Figure 13 shows both power output and Stirling efficiency over a lunar day/night cycle. 
TABLE 4.-PERFORMANCE SUMMARY USING VARIOUS ISOTOPES IN GPHS MODULE HOUSING

\begin{tabular}{|l|c|c|c|}
\hline \multicolumn{1}{|c|}{ Description } & $\begin{array}{c}\text { ASRG } \\
\text { Pu-238 }\end{array}$ & $\begin{array}{c}\text { ASRG } \\
\text { Am-241 }\end{array}$ & $\begin{array}{c}\text { ASRG } \\
\text { Sr-90 }\end{array}$ \\
\hline Mission duration, yr & 10 & 10 & 10 \\
\hline Stirling hot end temp, ${ }^{\circ} \mathrm{C}$ & 850 & 850 & 850 \\
\hline Stirling cold end temp, ${ }^{\circ} \mathrm{C}$ & 90 & 47 & 44 \\
\hline BOM heat, W & 500 & 112 & 85.6 \\
\hline AC output, W & 176 & 38 & 29 \\
\hline PC\&C power, W & 12 & 9 & 9 \\
\hline BOM DC power-nominal, W & 164 & 29 & 19 \\
\hline EOM DC power-nominal, W & 148 & 25 & 13 \\
\hline BOM daytime power (est.), W & 143 & 34 & 25 \\
\hline BOM night power (est.), W & 172 & 2 & 2 \\
\hline No. GPHS modules & 2 & 20.2 & 19.4 \\
\hline Mass, kg & 20.2 & 1.4 & 1.0 \\
\hline Specific power, W/kg & 8.1 & $\sim 26 \%$ & $\sim 23 \%$ \\
\hline BOM efficiency, percent & $\sim 32 \%$ & 46 & 46 \\
\hline Diameter, cm & 46 & 72 & 72 \\
\hline Length, cm & 72 & & \\
\hline
\end{tabular}

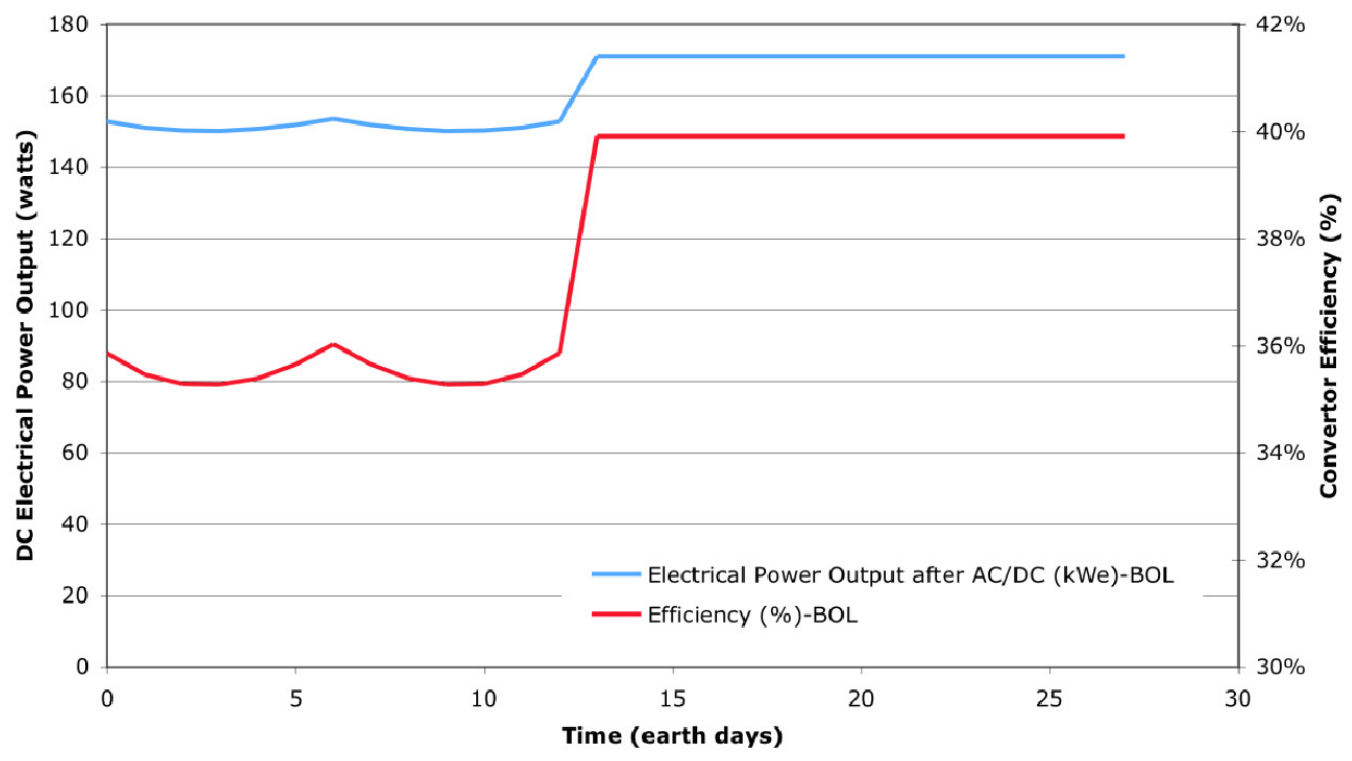

Figure 13.--Power output and efficiency as a function of time of day.

Power output increases during the night from 164 to $172 \mathrm{~W}$ as the environment temperature drops. As the isotope decays, thermal power output from the GPHS modules decrease and thereby reduces the power output of the ASRG. Nominal power for a 10-yr mission drops from 164 to $148 \mathrm{~W}$ while Stirling cold-end temperature drops from 360 to $350 \mathrm{~K}$. Figure 14 shows power output and Stirling cold-end temperature as a function of mission time for the Pu-238 ASRG. 


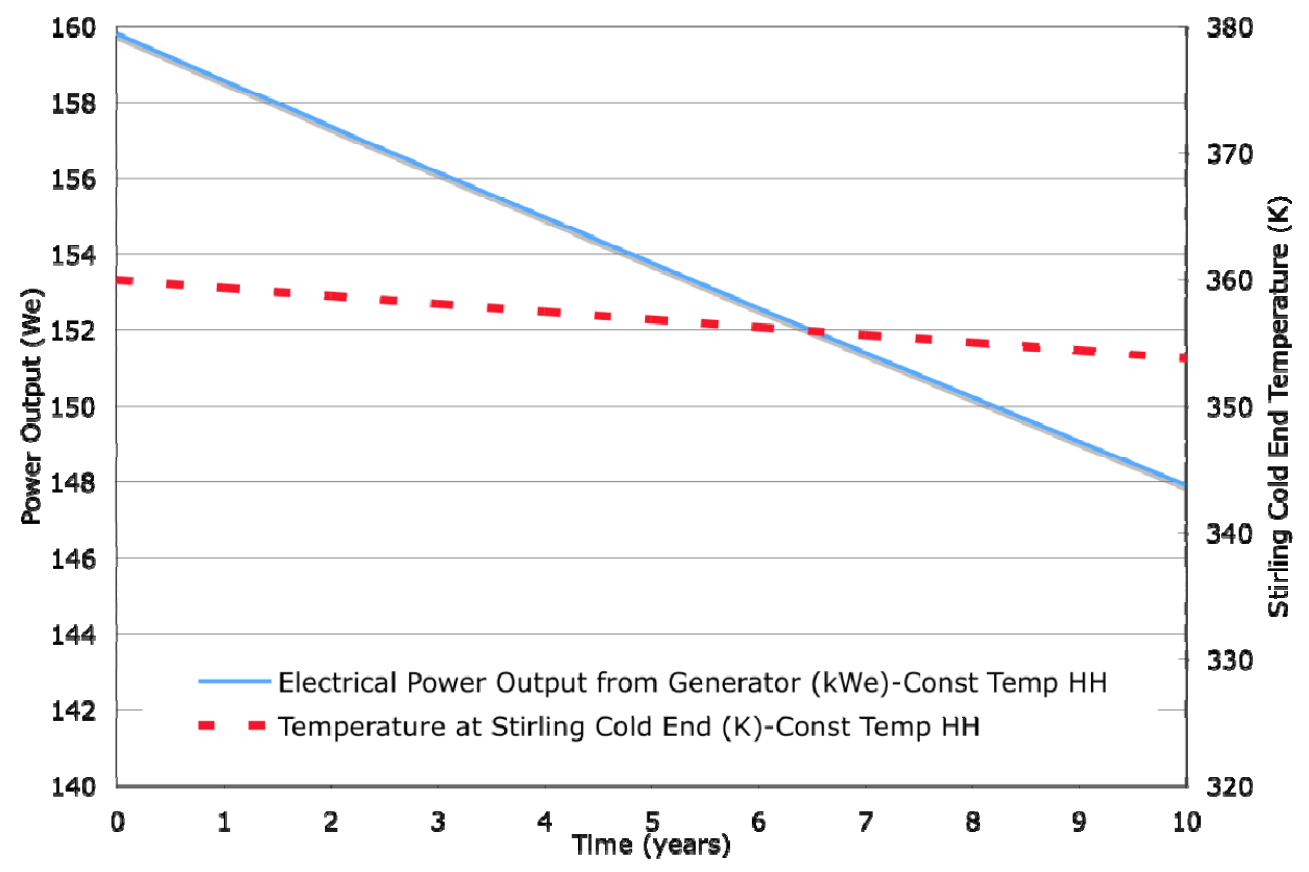

Figure 14.-Nominal power output as a function of mission.

\section{ASRG With Alternative Isotopes}

Direct replacement of the two Pu-238 GPHS modules with either Am-241 or Sr-90 GPHS filled modules was outlined earlier. Using Sr-90, system mass was reduced by $0.8 \mathrm{~kg}$ because of the decrease in GPHS module mass due to the lower density of the SrO fuel. Radiator, hot and cold side flanges, Stirling convertor, and all of the other components are assumed to be the same as in the ASRG. BOL power output is reduced significantly with the Am-241 system producing $29 \mathrm{~W}$ nominally and the Sr-90-based ASRG producing $20 \mathrm{~W}$. Table 4 shows a summary and comparison of the Pu-238-, Am-241-, and Sr-90based ASRGs. Controller power consumption is reduced but is a greater fraction of total power because although ac/dc conversion power throughput is reduced, the monitoring and system housekeeping power consumption remains constant. Because of the very long half-life of the Am-241 both power output and cold-end temperature remain nearly constant. Figures 15 and 16 show power output of the Am-241 ASRG as both a function of time and diurnal lunar cycle. Power output varies for the lunar day/night cycles in a similar fashion to that of the Pu-238-based system. Maximum power occurs during lunar night and is $34 \mathrm{~W}$ while minimum power occurs in midmorning and mid-afternoon with the ASRG providing $25 \mathrm{~W}$ of dc power. Sr-90-based ASRG, because of its short 28-yr half-life has a more rapid drop in power output than either of the two other systems. Power output under nominal conditions falls from $19 \mathrm{~W}$ BOL to $13 \mathrm{~W}$ at $10 \mathrm{yr}$. BOL power output varies from $25 \mathrm{~W}$ at night to $17 \mathrm{~W}$ during the day. Figures 17 and 18 show the power output changes. 


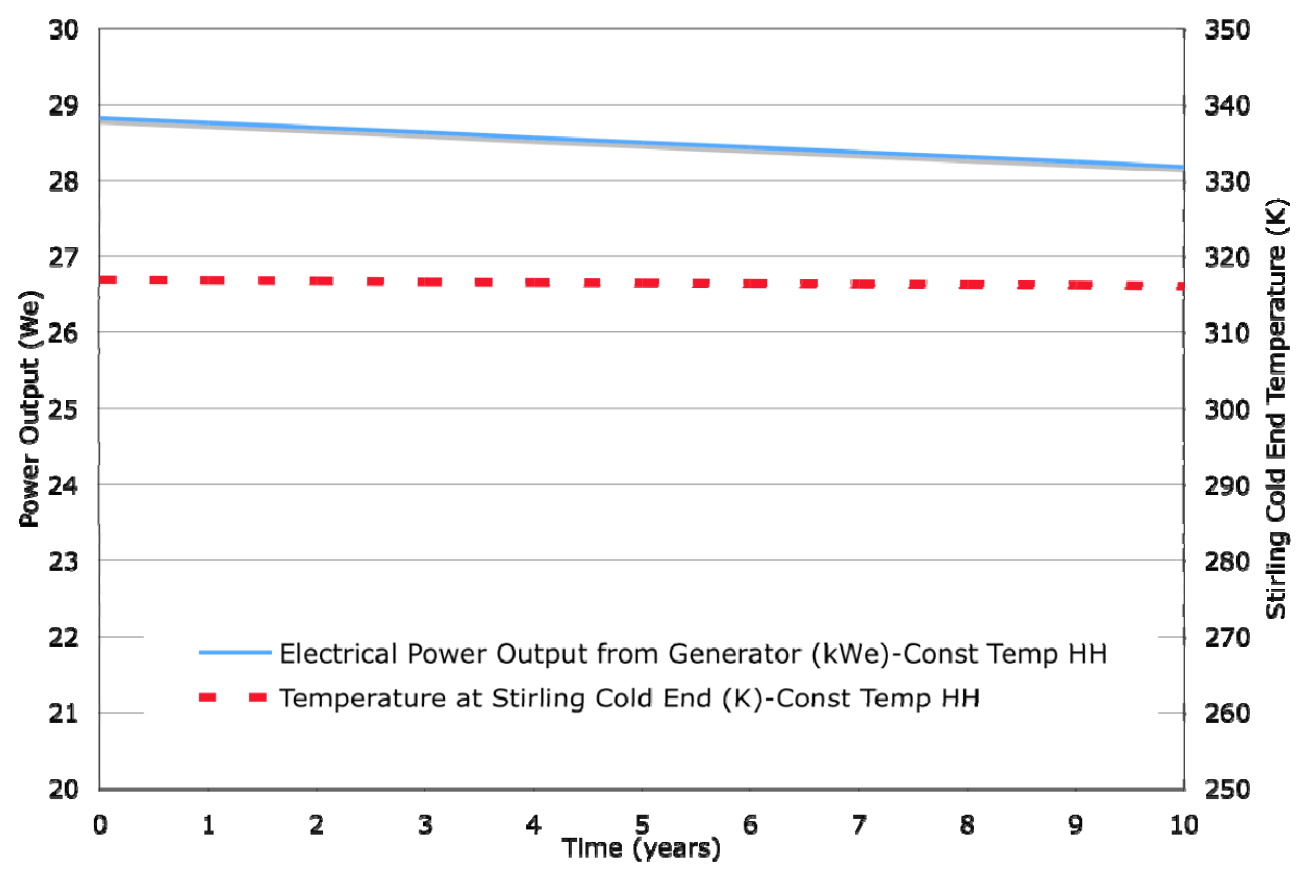

Figure 15.-Power output and Stirling cold-end temperature for an Am-241 GPHS ASRG.

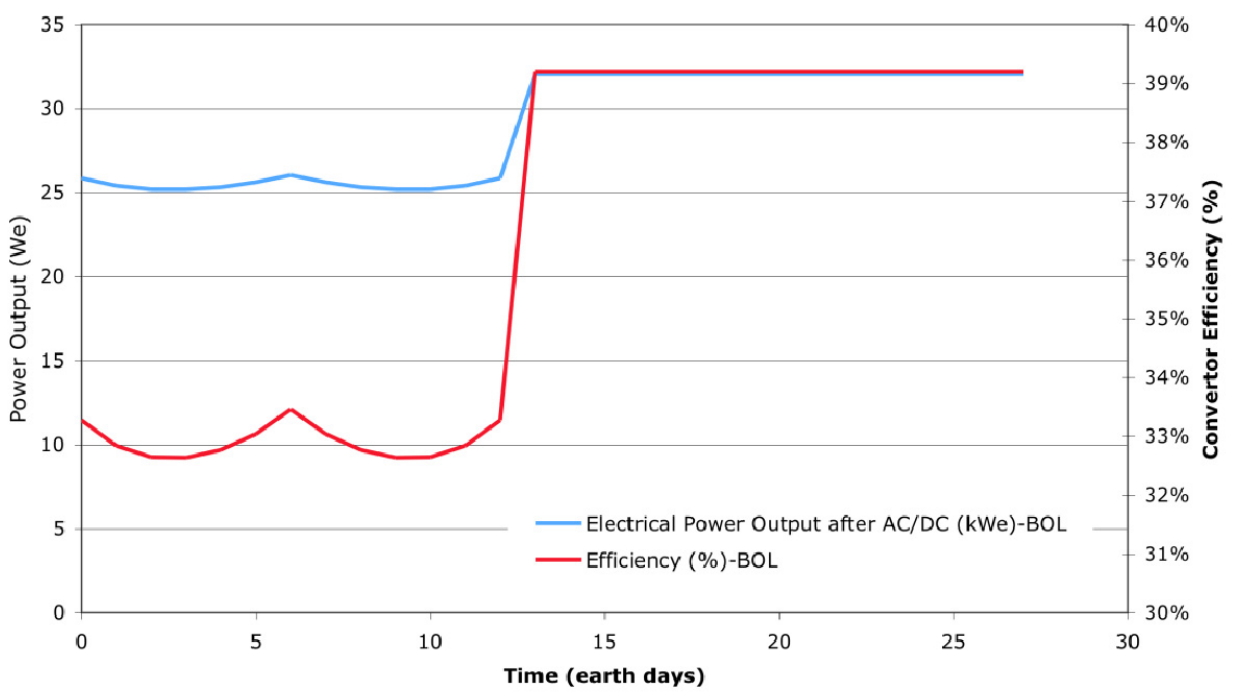

Figure 16.-Am-241 ASRG power and convertor efficiency as a function of lunar day/night cycle. 


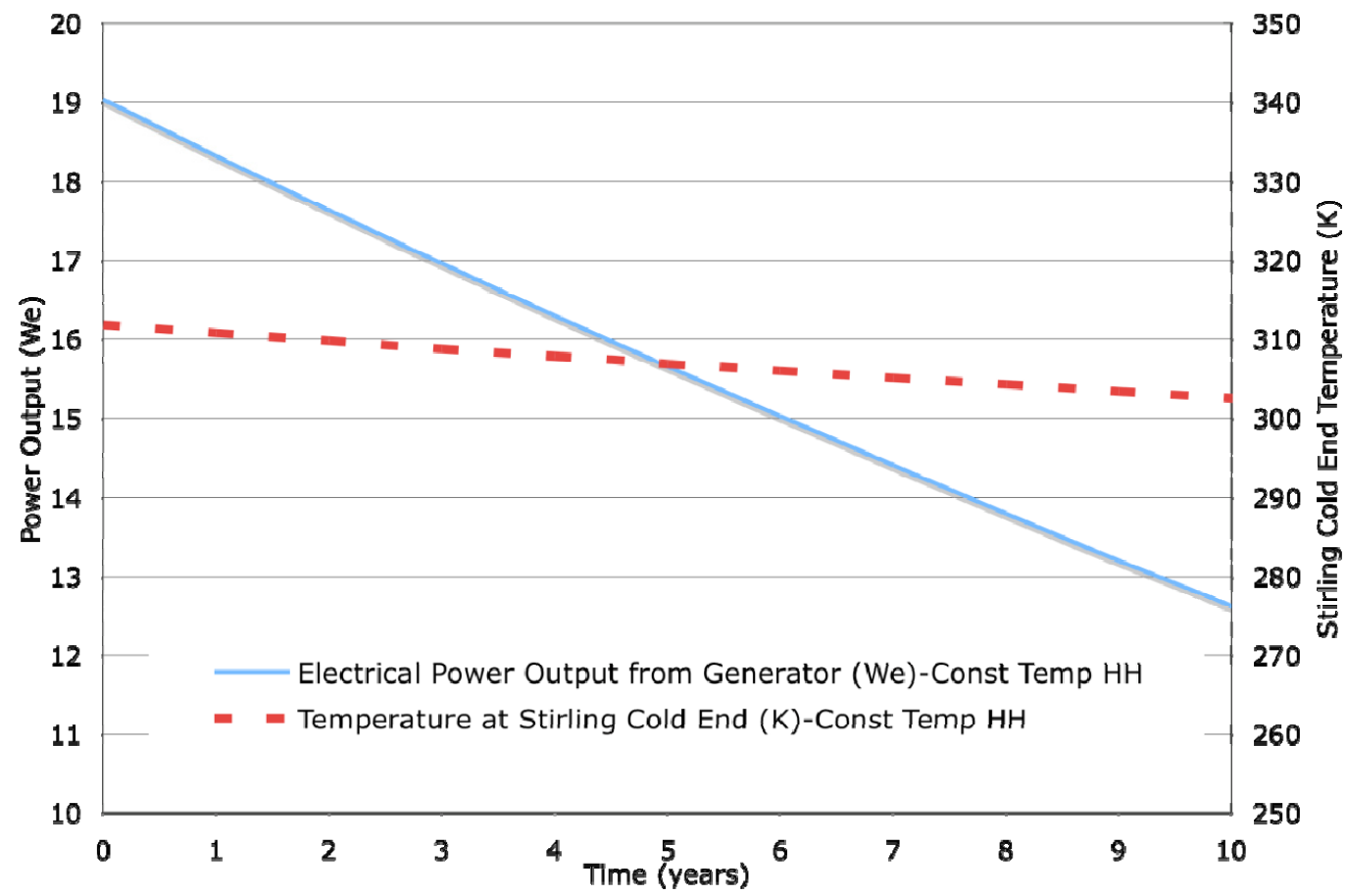

Figure 17.—Power output and Stirling cold-end temperature for a Sr-90 GPHS.

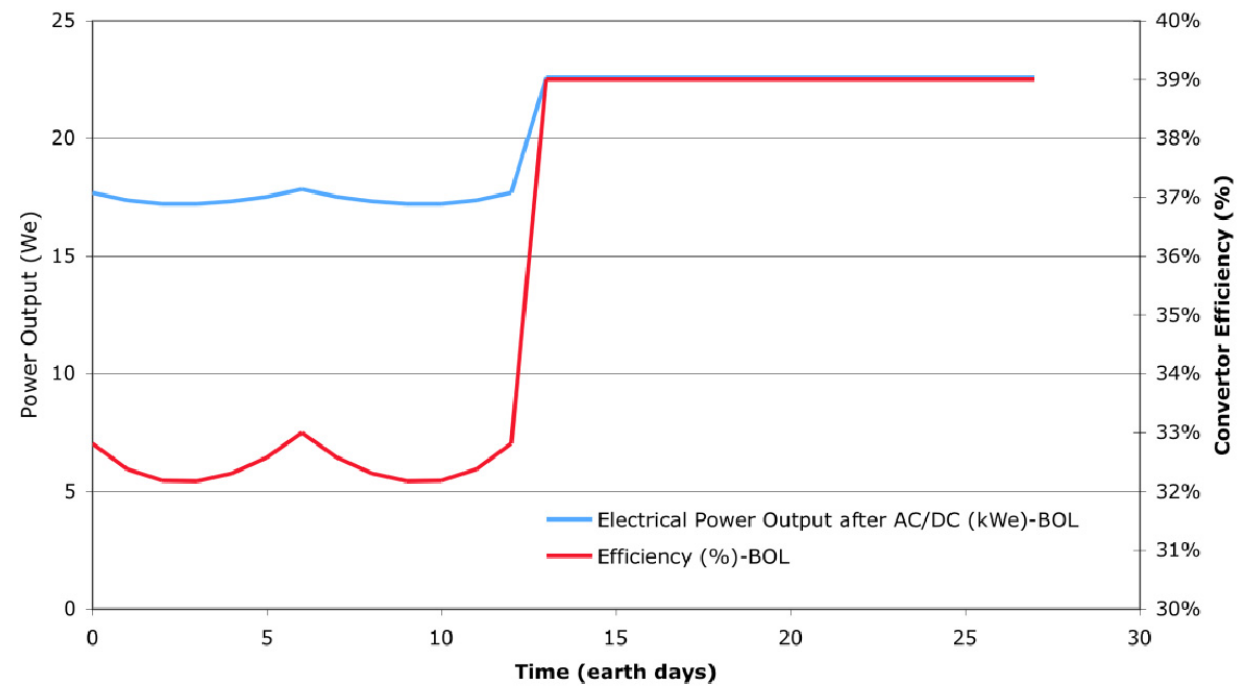

Figure 18.-Sr-90 ASRG power and convertor efficiency as a function of lunar day/night cycle. 
TABLE 5.-COMPARISON OF ALTERNATIVE ISOTOPE SYSTEMS WITH TWO GPHS MODULES

\begin{tabular}{|l|c|c|c|}
\hline \multicolumn{1}{|c|}{ Description } & $\begin{array}{c}\text { ASRG } \\
\text { Pu-238 }\end{array}$ & $\begin{array}{c}\text { ASRG } \\
\text { Am-241 }\end{array}$ & $\begin{array}{c}\text { ASRG } \\
\text { Sr-90 }\end{array}$ \\
\hline Mission duration, $\mathrm{yr}$ & 10 & 10 & 10 \\
\hline Stirling hot end temp, ${ }^{\circ} \mathrm{C}$ & 850 & 850 & 850 \\
\hline Stirling cold end temp, ${ }^{\circ} \mathrm{C}$ & 90 & 52 & 52 \\
\hline BOM heat, W & 500 & 114 & 86 \\
\hline AC output, W & 176 & 38 & 27 \\
\hline PC\&C power, W & 12 & 9 & 9 \\
\hline BOM DC power-nominal, W & 164 & 29 & 20 \\
\hline EOM DC power-nominal, W & 148 & 29 & 14 \\
\hline BOM daytime power (est.), W & 143 & 25 & 15 \\
\hline BOM night power (est.), W & 172 & 34 & 22 \\
\hline No. GPHS modules & 2 & 2 & 2 \\
\hline Mass, kg & 20.2 & 11 & 9 \\
\hline Specific power, W/kg & 8.1 & 2.6 & 2.1 \\
\hline BOM efficiency, percent & $33 \%$ & $25 \%$ & $21 \%$ \\
\hline
\end{tabular}

\section{Alternative Isotope With Optimized ASRG System}

The previous section described the direct replacement of the Pu-238 GPHS modules with both Am-241 and Sr-90. Both the Am-241 and Sr-90 systems produced one-fifth the power but system mass was nearly identical because it was assumed that all of the ASRG components were both the same mass and size. If a new optimized system including an optimized convertor, smaller radiator, reduction in heat input/rejection flange masses, significant improvements in system mass and performance may be possible. Table 5 shows estimates for two GPHSs optimized for best specific power (W/kg). The two GPHS Am-241 systems increased its specific power over the direct ASRG replacement from 1.4 to $2.6 \mathrm{~W} / \mathrm{kg}$ and the Sr-90 specific mass improved from 1 to $2.1 \mathrm{~W} / \mathrm{kg}$.

\section{Controllers}

Stirling convertor controllers are used to ensure that the convertor operates within its given design specifications over its life. There are many control strategies that could be implemented for a Stirling isotope power system but emphasis in this paper is placed on control strategies that fix one parameter. Two control strategies are explored here to help understand the differences on system operating conditions with each control strategy. One control strategy is to fix the heater head temperature for the mission duration. In order to maintain this temperature with varying environmental conditions and the reduction in heat produced as the isotope decays the engine stroke is varied. By changing the stroke the convertor will pull more or less heat through the engine to maintain a constant heater head temperature.

A second control scheme is to fix the heat input into the convertor. This is similar to what occurs when the stroke is held at a constant amplitude. The advantage of this control strategy is that only piston position is needed and the voltage on the alternator of the Stirling convertor is varied to achieve the desired stroke. Figure 19 shows a plot of heater head temperature and efficiency for a Pu-238-based ASRG with both the constant temperature heater head and constant heat input for the ASRG. Constant heat input control produces a reduction in heater head temperature as mission time increases. At $10 \mathrm{yr}$, the heater head temperature has dropped from $1123 \mathrm{~K}$ at BOM to about $800 \mathrm{~K}$ with a corresponding drop in efficiency. Figure 20 shows power output and Stirling cold-end temperature as a function of mission time. For the constant heater head temperature control, power output drops from 160 to $148 \mathrm{~W}$ while for the constant heat input control, power output drops from 160 to $138 \mathrm{~W}$. Cold-end temperature drops slightly for the fixed heater head temperature control (360 to $350 \mathrm{~K}$ ) while for the fixed heat input cold-end temperature rises from 360 to $367 \mathrm{~K}$. Because the isotope is decaying, the total heat generated by the GPHS modules is falling as time passes. In this model heat into the Stirling convertor is the difference between heat generated by the GPHS modules at any given time and that heat lost through the insulation. 
Insulation thickness is fixed at the design point BOM from the temperature of the outer surface of the GPHS and the sink temperature and the difference between heat required by the engine and that generated by the GPHS modules. To maintain a constant heat input into the heater head the losses from the decaying isotope must be made up for by losing less through the insulation. Therefore the temperature of the hot end must decrease until the insulation loss is reduced by the amount needed to make up for the decaying isotope. As the hot-end temperature drops, but with a fixed thermal throughput into the engine and a fixed radiator area, the Carnot efficiency will drop. This leads to a rise in cold-end temperature. Other methods or hybrid methods were not considered for this study.

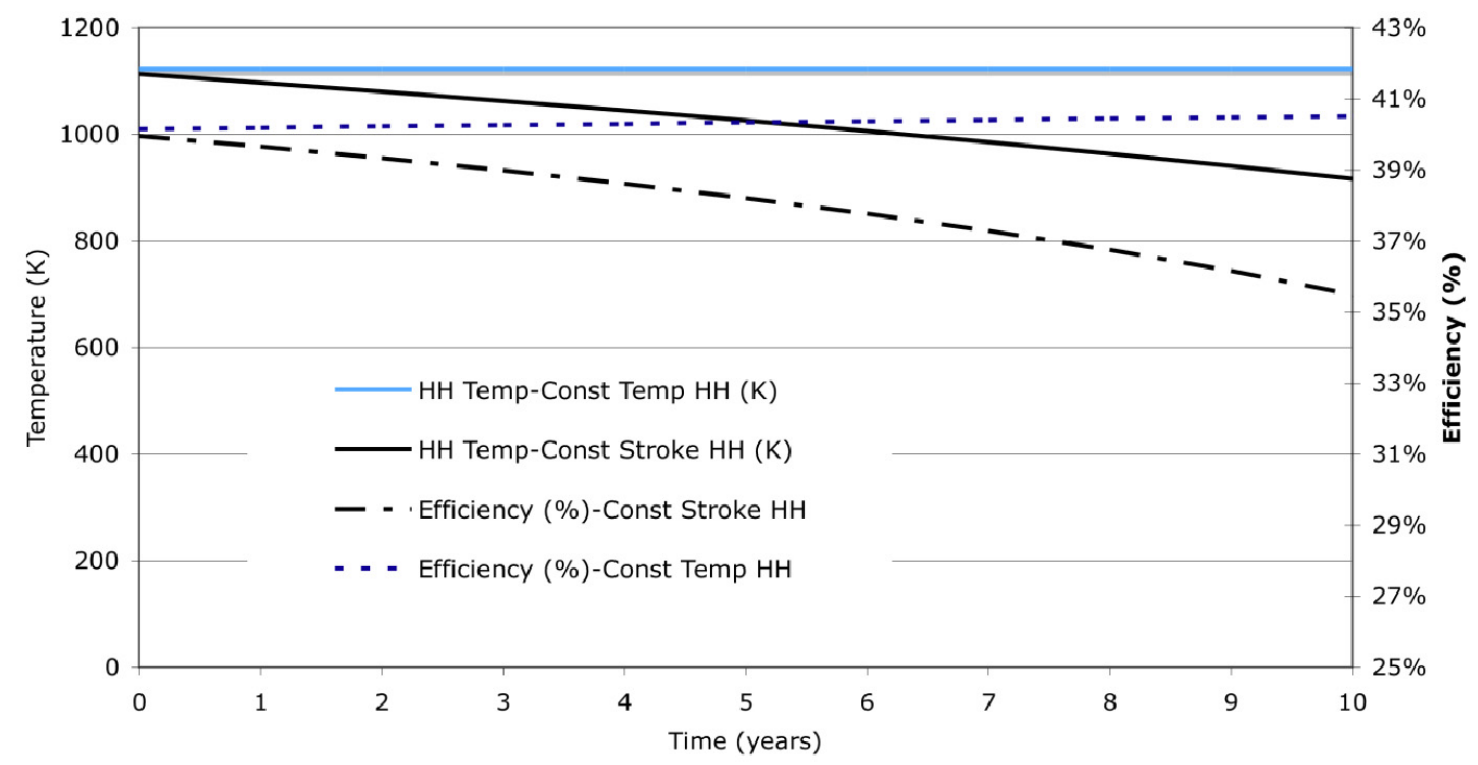

Figure 19.- - Heater head temperature and efficiency for a Pu-238 system with different control strategies.

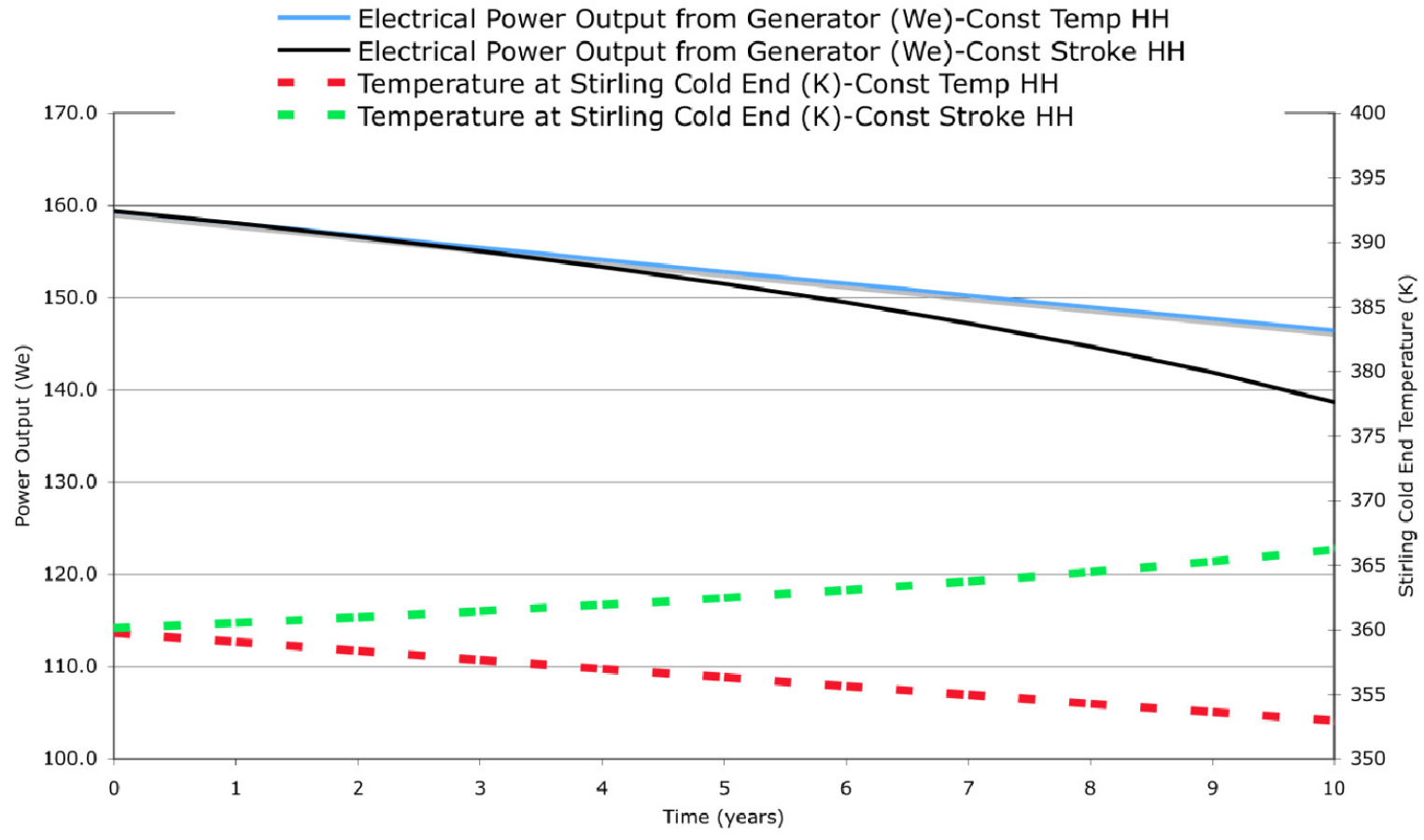

Figure 20.-_Power output and Stirling cold end for a Pu-238 system using different control strategies. 


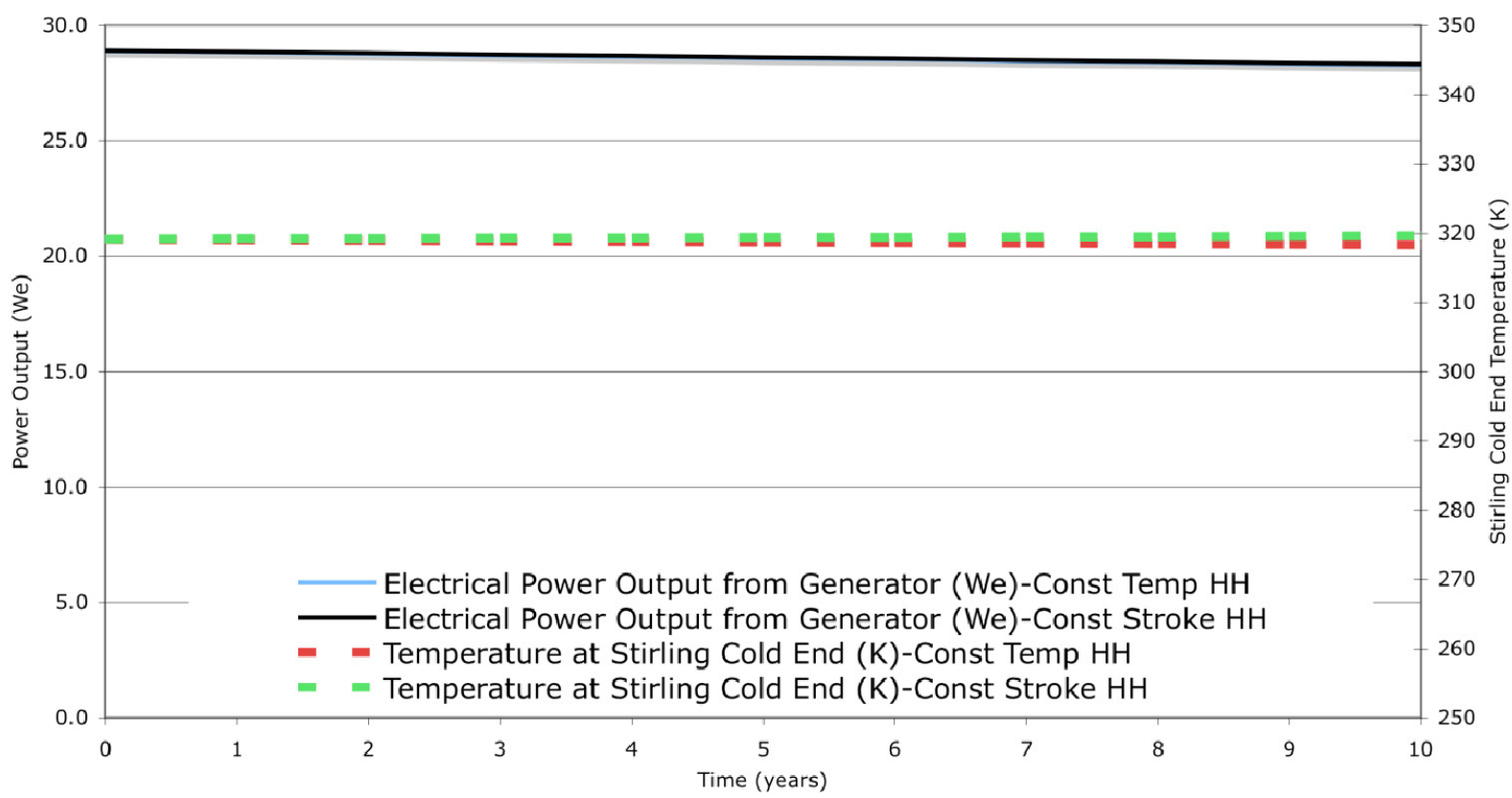

Figure 21.-Am-241 power output and cold-end temperature as a function of time and convertor control method.

TABLE 6.-COMPARISON OF 160 We Am-241 AND Pu-238 SYSTEMS

\begin{tabular}{|l|c|c|}
\hline \multicolumn{1}{|c|}{ Description } & $\begin{array}{c}\text { ASRG } \\
\text { Pu-238 }\end{array}$ & $\begin{array}{c}\text { Optimized ASRG } \\
\text { Am-241 }\end{array}$ \\
\hline Mission duration, yr & 10 & 10 \\
\hline Stirling hot end temp, ${ }^{\circ} \mathrm{C}$ & 850 & 850 \\
\hline Stirling cold end temp, ${ }^{\circ} \mathrm{C}$ & 90 & 87 \\
\hline BOM heat, W & 500 & 569 \\
\hline AC output, W & 176 & 171 \\
\hline PC\&C power, W & 12 & 11 \\
\hline BOM DC power-nominal, W & 164 & 160 \\
\hline EOM DC power-nominal, W & 148 & 157 \\
\hline BOM daytime power (est.), W & 143 & 146 \\
\hline BOM night power (est.), W & 172 & 174 \\
\hline No. GPHS modules & 2 & 10 \\
\hline Mass, kg & 20.2 & 41 \\
\hline Specific power, $\mathrm{W} / \mathrm{kg}$ & 8.1 & 3.9 \\
\hline BOM efficiency, percent & $33 \%$ & $28 \%$ \\
\hline
\end{tabular}

Figure 21 shows power output as a function of time for the two controller architectures using both Am-24land cold-end temperatures. Because of the very long half-life of Am-241, both control schemes produce similar results with respect to performance and very stable power output over the entire mission life. Power for the constant temperature heater head falls from 29 to $28 \mathrm{~W}$ over the 10 -yr mission while for the constant heat input control drops to $27 \mathrm{~W}$ at EOL.

\section{ASRG Using Pu-238 and Am-241}

Next we explore what a RPS might look like if it was required to produce $160 \mathrm{~W}$ BOL identical to what the ASRG does except with Am-241. In order for the Americium system to produce $160 \mathrm{~W}$, 10 Am-241 GPHS modules ( 5 per convertor side times 2 convertors $=10)$ must be arranged around each heater head to minimize the impact of conduction losses from the GPHS surface to the heater head. Table 6 shows mass for the system has approximately doubled due to the much greater number of GPHS modules, the added insulation, and its associated equipment. Cold-end mass is similar while overall efficiency has dropped by 5 percent due to the increased losses associated with the larger heat source area. 


\section{Maximum Power Output of Conductively Coupled ASRG}

Integration of multiple GPHSs with a single Stirling becomes mass prohibitive at some point due to the increasing distance between the GPHS and the Stirling and the mass associated with integrating the two systems. Earlier analysis suggested over six GPHSs per convertor, the system-specific mass began to decrease above $1 \mathrm{kWe}$ for a Pu-238 system. Because the total heat rejected is similar to what is found in the Pu-238 ASRG for the 5 GPHS module Am-241 system, the cold-end size and operational temperatures are very similar. For the Pu- 238 system with five GPHSs the heat rejected has increased by a factor of 5 over both the 160-W Am-241 system and the ASRG. The conductively coupled design cold end takes the heat from the cold flange, and conducts via a conductive collar out to the ASRG casing and rejects the heat to space. The dramatic increase in heat rejected makes the conductively coupled cold-end design impractical. One method to improve heat transfer from the cold end to the radiator surface is to connect heat pipes to the cold end of the convertor and run these out to the surface of the radiator. For this five-GPHS Pu-238 design, water heat pipes are used to improve performance and spread the heat from the cold end of the convertor to the surface of the radiator. Details of this design can be found in Reference 15. Table 7 shows a comparison of both the Am-241 and Pu-238 systems conductively coupled systems with five GPHSs.

TABLE 7.-COMPARISON OF FIVE GPHS Pu-238 AND Am-241 SYSTEMS

\begin{tabular}{|l|c|c|}
\hline \multicolumn{1}{|c|}{ Description } & 5 GPHS Pu-238 System & 5 GPHS Am-241 System \\
\hline Mission duration, yr & 10 & 10 \\
\hline Stirling hot end temp, ${ }^{\circ} \mathrm{C}$ & 850 & 850 \\
\hline Stirling cold end temp, ${ }^{\circ} \mathrm{C}$ & 87 & 87 \\
\hline BOM heat, W & 2500 & 569 \\
\hline AC output, W & 820 & 171 \\
\hline PC\&C power, W & 20.44 & 11 \\
\hline BOM DC power-nominal, W & 800 & 160 \\
\hline EOM DC power-nominal, W & 741.7 & 157 \\
\hline BOM daytime power (est.), W & 745.2 & 146 \\
\hline BOM night power (est.), W & 885.9 & 174 \\
\hline No. GPHS modules & 10 & 10 \\
\hline Mass, kg & 111.2 & 41 \\
\hline Specific power, W/kg & 7.2 & 3.9 \\
\hline BOM efficiency, percent & $32 \%$ & $28 \%$ \\
\hline Radiator area, $\mathrm{m}^{2}$ & 7.2 & 0.9 \\
\hline
\end{tabular}

\section{Pumped Loop Systems}

As was discussed earlier, the GPHS modules are attached to a metal conduction plate, which makes up one side of the heat exchanger with liquid $\mathrm{NaK}$ flowing on the other. Multilayer insulation (MLI) and a aluminum housing covers the entire heat source assembly. Heat loss through the insulation, structure, and piping is set to 5 percent of the total heat generated with a fixed 2.5 percent heat loss assumed through the piping and structure and a 2.5 percent heat loss through the surface of the HX. The area's temperatures and allowable heat loss through the pipes and HX, sizes the thickness of the MLI. Heat is taken from the heat source assembly via a flowing NaK loop and moved to the two Stirling convertors. It is necessary to ensure that the primary loop $\mathrm{NaK}$ does not flash to vapor and this is accomplished by maintaining sufficient pressure in the system with an accumulator such that the operating pressure is below the vapor pressure of the $\mathrm{NaK}$. Figure 22 shows the vapor pressure of $\mathrm{NaK}$ as a function of temperature along with the maximum operating temperature in the primary loop for both Stirling systems modeled. Maximum vapor pressure occurs for the high-temperature Stirling system at $1133 \mathrm{~K}$ and is 1.84 bar. The $\mathrm{NaK}$ is pumped around the hot side of the system with two series annular linear induction electromagnetic pumps (ALIPs). The series configuration is possible because the ALIPs are open channel pumps with external coils that provide a magnetic field. The ALIPS have efficiency of 15 percent. The heat rejection system for this case is assumed to be a north-south vertically oriented radiator. Water is 
NaK Vapor Pressure as a Function of Temperature

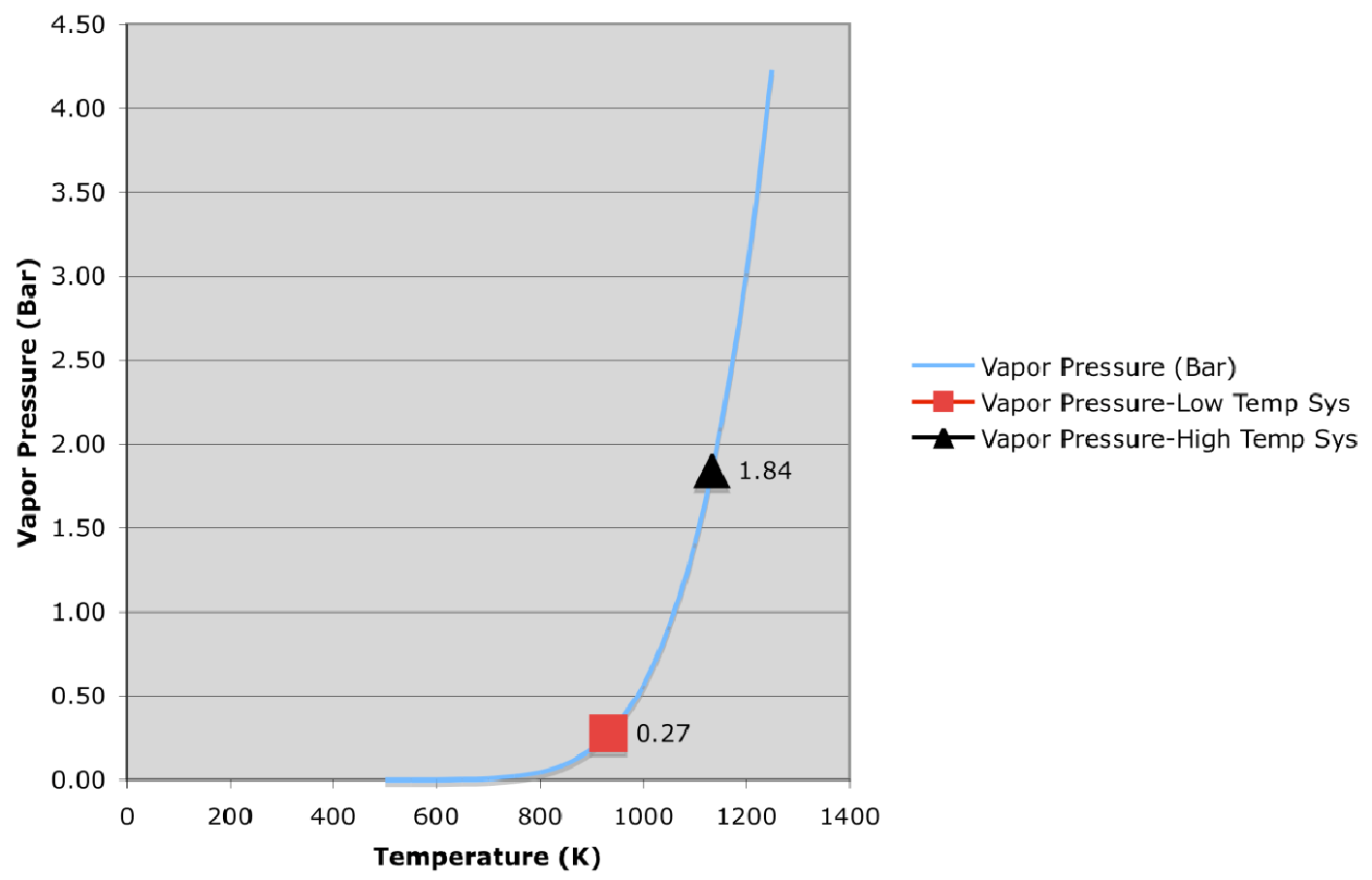

Figure 22.-NaK vapor pressure versus temperature.

used as the working fluid and two parallel impellar pumps provide its motivation. The water loop is in contact with water heat pipes bonded to the outside of the water pumped loop, which are embedded within a graphite heat rejection radiator that is discussed above. A range of Stirling cold-end temperatures are modeled and trades are made between minimum mass and GPHS modules.

Power levels of 1,2, and $5 \mathrm{kWe}$ and maximum heater head temperatures of 923 and $1123 \mathrm{~K}$ are modeled for this study. Figures 23 and 24 show mass and the number of GPHS modules for a 1-kWe, $923 \mathrm{~K}$ system using both a Pu-238 and Am-241 as a function of Stirling cold-end temperature. Minimum mass for the Pu- 238 system occurs at $400 \mathrm{~K}$ while for the Am-241 system occurs at $360 \mathrm{~K}$. Figures 25 and 26 show the relative mass fractions for the major system components operating at a cold-end temperature of $360 \mathrm{~K}$. Because of the much lower thermal output of the Am-241 when compared with the $\mathrm{Pu}-238$ system, the GPHS module and heat source mass in a more significant fraction of the overall system mass and the minimum mass system Stirling cold-end temperature, drops to reduce the GPHS module count. Mass fraction of the GPHS modules for the Pu-238 system is 16 percent while for the Am-241 system is 36 percent. Additionally, insulation mass has increased from 3 to 5 percent due to the significantly higher number of GPHS modules and greater surface area.

Figures 27 and 28 show the same mass and GPHS count plots with the exception of an $1123 \mathrm{~K}$ heater head temperature for both. Mass for the Pu-238 systems has been decreased by 10 percent with the change in heater head temperature while GPHS count has dropped by 16 to 12 . For the Am-241 system mass has dropped by about 13 percent while Am-241 GPHS module count has dropped from 67 to 53 . 


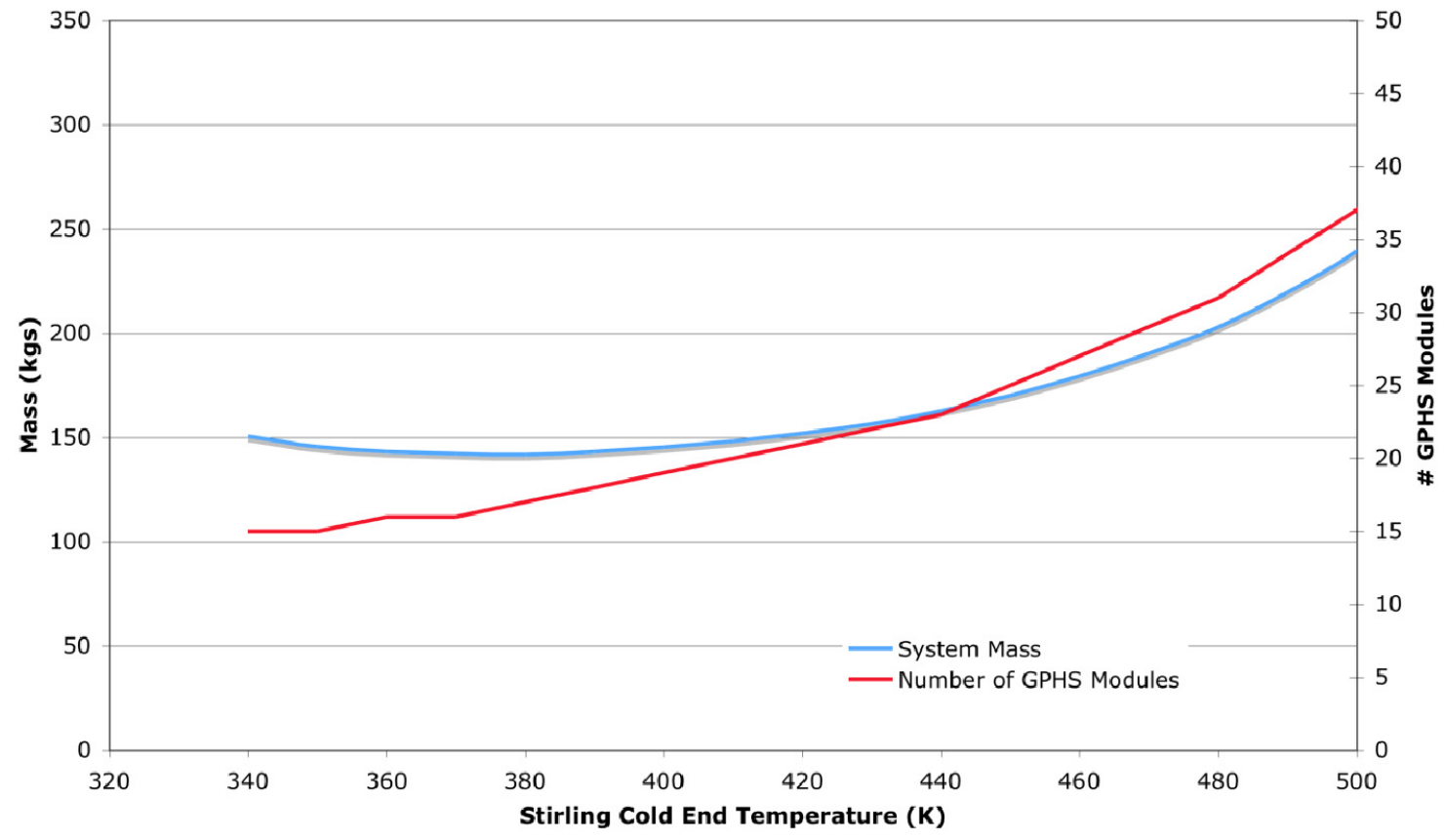

Figure 23.-1-kWe Pu-238 pumped loop system, $923 \mathrm{~K}$ heater head temperature.

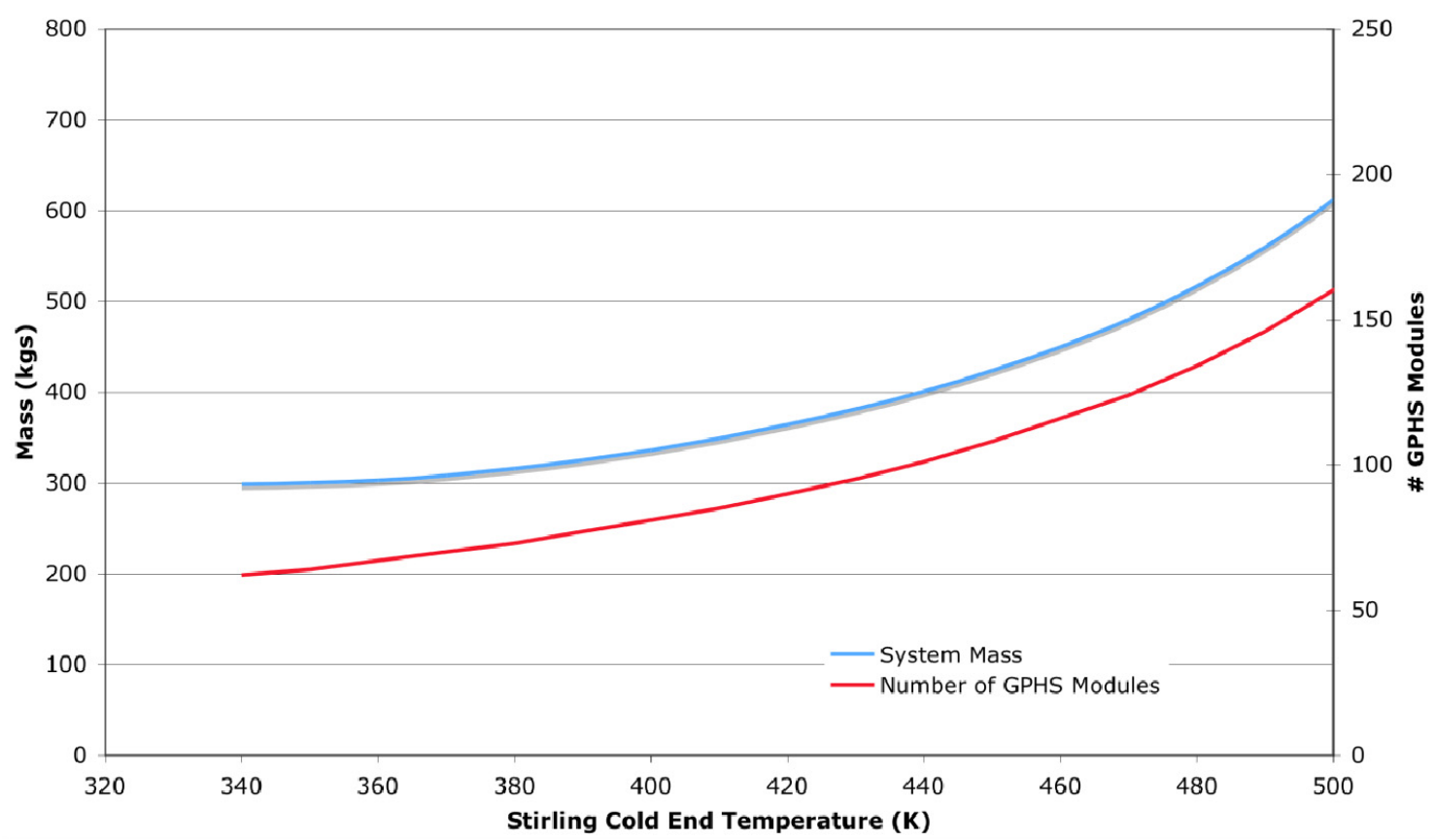

Figure 24.-1-kWe $\mathrm{AmO}_{2}$ pumped loop system, $923 \mathrm{~K}$ heater head temperature. 


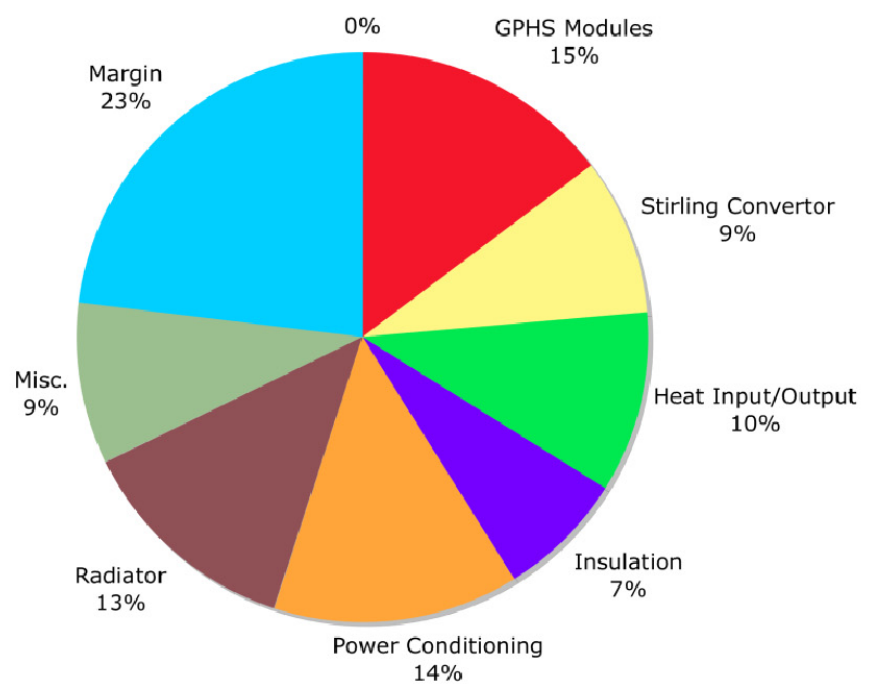

Figure 25.-Mass fraction for a 1-kWe $1123 \mathrm{~K}$ heater head Pu-238 system.

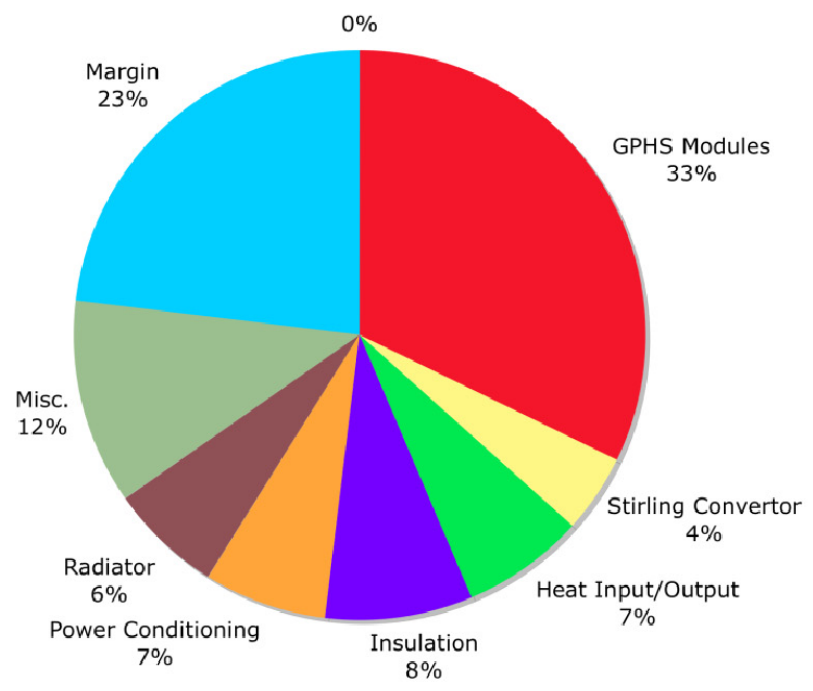

Figure 26.-Mass fraction for a 1-kWe $1123 \mathrm{~K}$ heater head Am-241 system. 


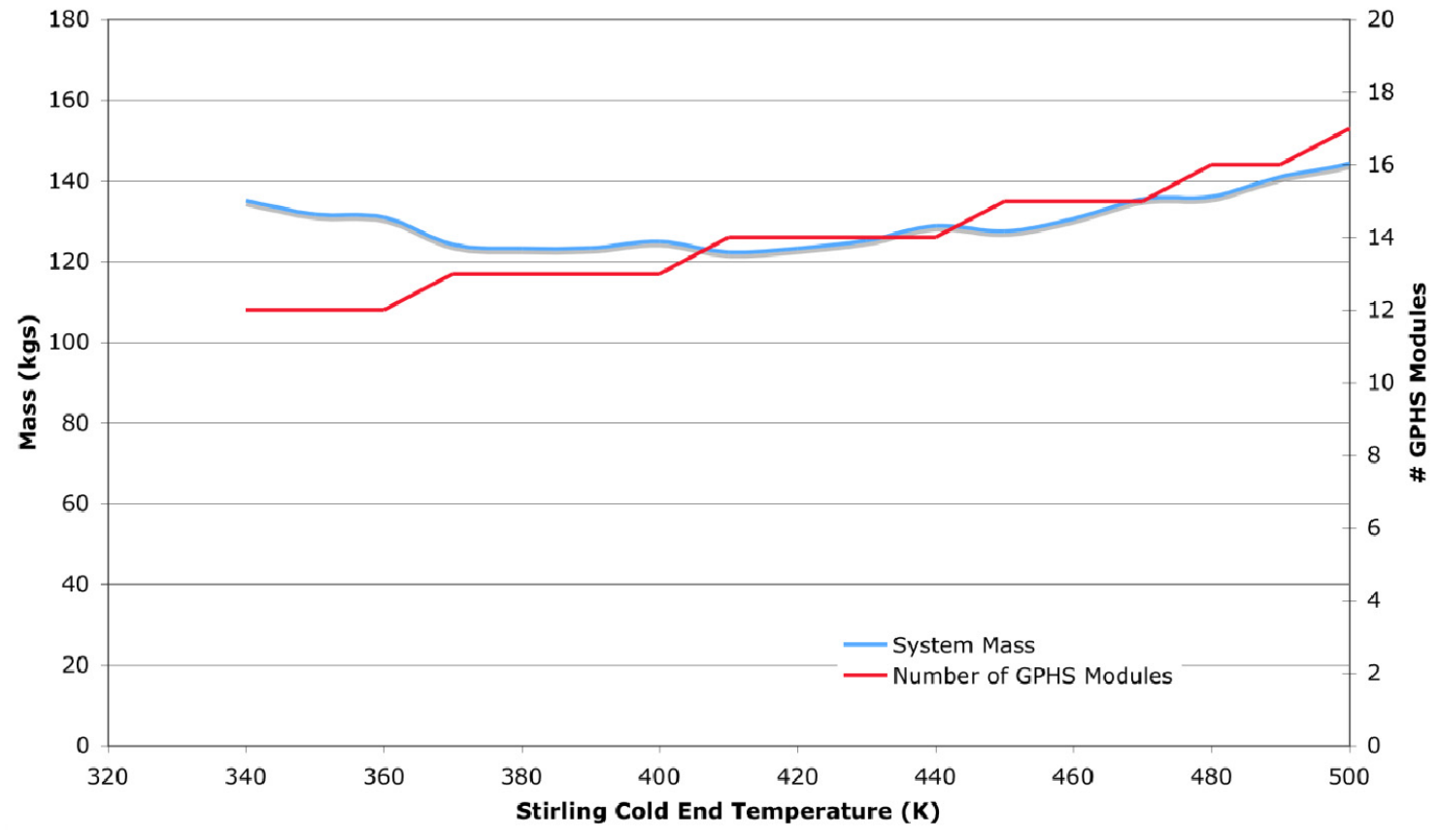

Figure 27.-1-kWe Pu-238 pumped loop system, $1123 \mathrm{~K}$ heater head temperature.

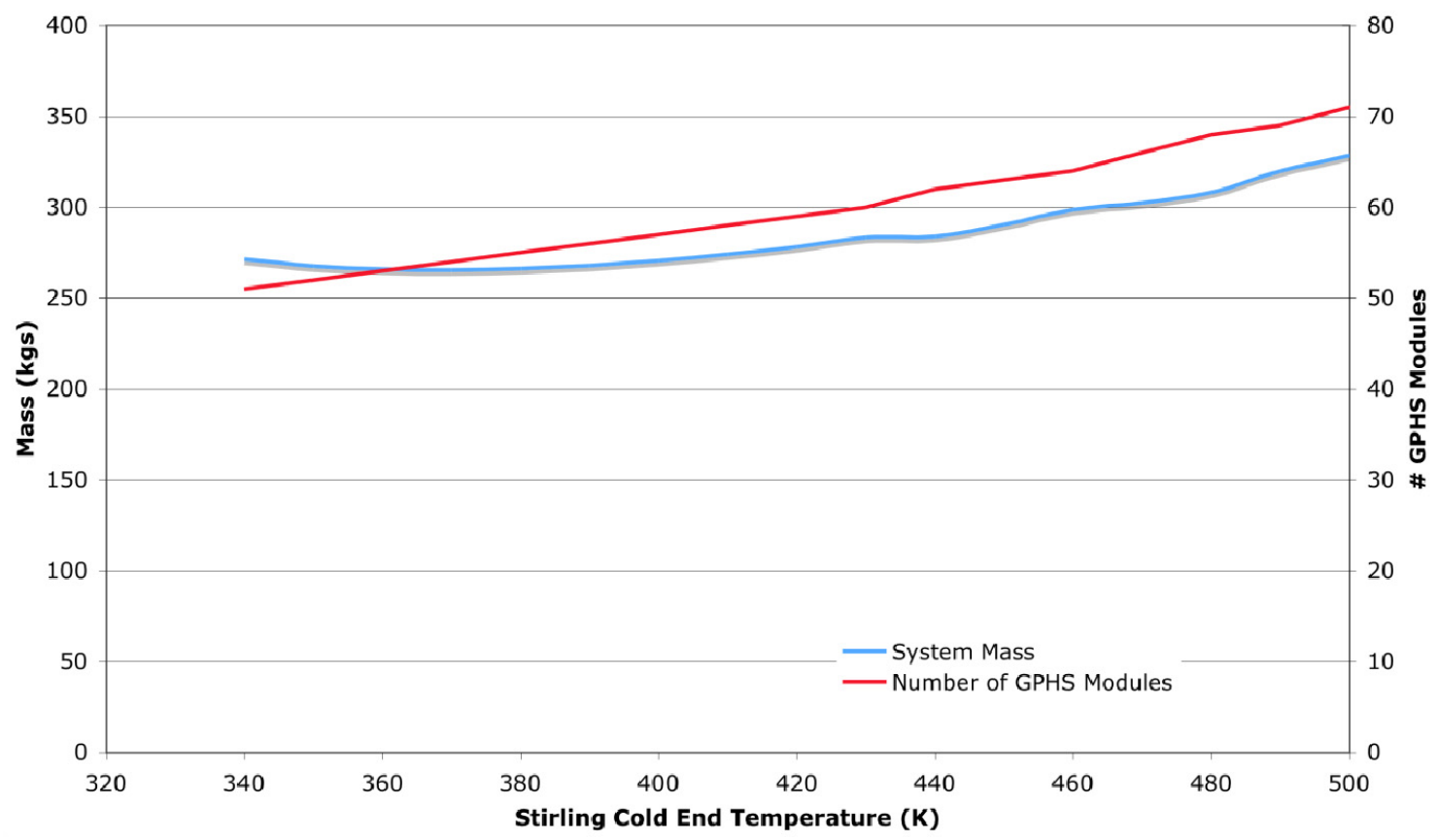

Figure 28.-1-kWe Am-241 pumped loop system, $1123 \mathrm{~K}$ heater head temperature. 
Tables 8 and 9 show the 1,2, and $5 \mathrm{kWe}$ for both the $923 \mathrm{~K}$ heater head systems and the $1123 \mathrm{~K}$ systems with both $\mathrm{Pu}-238$ and $\mathrm{Am}-241$ GPHS modules. Pu-238 systems are about half the system mass of the Am-241 systems with this change growing with increasing power level. Heater head temperature reduces system mass by about 10 percent at $1 \mathrm{kWe}$ and growing to about 20 percent at $5 \mathrm{kWe}$. Figure 29 shows a comparison of the 923 and $1123 \mathrm{~K}$ system from 1 to $5 \mathrm{kWe}$ for both Pu-238 and Am-241.

TABLE 8.-1-, 2-, AND 5-kWe Pu-238 AND Am-241 SYSTEMS WITH A $923 \mathrm{~K}$ MAXIMUM HEATER HEAD TEMPERATURE

\begin{tabular}{|l|c|c|c|c|c|c|}
\hline \multicolumn{1}{|c|}{ Description } & $\begin{array}{c}1 \mathrm{kWe} \mathrm{Pu}- \\
238 \mathrm{System}\end{array}$ & $\begin{array}{c}2 \mathrm{kWe} \mathrm{Pu}-238 \\
\text { system }\end{array}$ & $\begin{array}{c}5 \mathrm{kWe} \mathrm{Pu}-238 \\
\text { system }\end{array}$ & $\begin{array}{c}1 \mathrm{kWe} \mathrm{Am}- \\
241 \text { system }\end{array}$ & $\begin{array}{c}2 \mathrm{kWe} \mathrm{Am}- \\
241 \text { system }\end{array}$ & $\begin{array}{c}5 \mathrm{kWe} \mathrm{Am}- \\
241 \mathrm{system}\end{array}$ \\
\hline Isotope & $\mathrm{PuO}_{2}$ & $\mathrm{PuO}_{2}$ & $\mathrm{PuO}_{2}$ & $\mathrm{AmO}_{2}$ & $\mathrm{AmO}_{2}$ & $\mathrm{AmO}_{2}$ \\
\hline Heat source integration method & $\begin{array}{c}\text { Pumped } \\
\text { loop }\end{array}$ & Pumped loop & Pumped loop & $\begin{array}{c}\text { Pumped } \\
\text { loop }\end{array}$ & $\begin{array}{c}\text { Pumped } \\
\text { loop }\end{array}$ & $\begin{array}{c}\text { Pumped } \\
\text { loop }\end{array}$ \\
\hline Mission duration, yr & 10 & 10 & 10 & 10 & 10 & 10 \\
\hline Stirling hot end temp, ${ }^{\circ} \mathrm{C}$ & 913 & 913 & 913 & 913 & 913 & 913 \\
\hline Stirling cold end temp, ${ }^{\circ} \mathrm{C}$ & 360 & 360 & 360 & 360 & 360 & 360 \\
\hline Temperature ratio & 2.54 & 2.54 & 2.54 & 2.54 & 2.54 & 2.54 \\
\hline BOM heat, W & 4000 & 7750 & 19250 & 3812 & 7625 & 19175 \\
\hline AC output, W & 1075 & 2151 & 5376 & 1075 & 2151 & 5376 \\
\hline PC\&C power, W & 23 & 38 & 81 & 23 & 38 & 81 \\
\hline BOM DC power-nominal, W & 1000 & 2000 & 5000 & 1000 & 2000 & 5000 \\
\hline EOM DC power-nominal, W & 919 & 1844 & 4612 & 986 & 1971 & 4927 \\
\hline BOM daytime power (est.), W & 904 & 1806 & 4509 & 905 & 1809 & 4518 \\
\hline BOM nightime power (est.), W & 1045 & 2090 & 5226 & 1047 & 2094 & 5236 \\
\hline No. GPHS modules & 16 & 31 & 77 & 67 & 134 & 337 \\
\hline System mass, kg & 143 & 268 & 648 & 303 & 581 & 1426 \\
\hline Specific power, W/kg & 7.5 & 8.0 & 8.3 & 3.5 & 3.7 & 3.8 \\
\hline BOM efficiency, percent & $25 \%$ & $26 \%$ & $26 \%$ & $26 \%$ & $26 \%$ & $26 \%$ \\
\hline
\end{tabular}

TABLE 9.-1-, 2-, AND 5-kWe Pu-238 AND Am-241 SYSTEMS WITH A 1123 K MAXIMUM HEATER HEAD TEMPERATURE

\begin{tabular}{|c|c|c|c|c|c|c|}
\hline Description & $\begin{array}{c}1 \mathrm{kWe} \mathrm{Pu}-238 \\
\text { System }\end{array}$ & $\begin{array}{c}2 \mathrm{kWe} \mathrm{Pu}-238 \\
\text { system }\end{array}$ & $\begin{array}{l}5 \mathrm{kWe} \mathrm{Pu}- \\
238 \text { system }\end{array}$ & $\begin{array}{l}1 \mathrm{kWe} \text { Am- } \\
241 \text { system }\end{array}$ & $\begin{array}{l}2 \mathrm{kWe} \text { Am- } \\
241 \text { system }\end{array}$ & $\begin{array}{l}5 \mathrm{kWe} \mathrm{Am-} \\
241 \text { system }\end{array}$ \\
\hline Isotope & $\mathrm{PuO}_{2}$ & $\mathrm{PuO}_{2}$ & $\mathrm{PuO}_{2}$ & $\mathrm{AmO}_{2}$ & $\mathrm{AmO}_{2}$ & $\mathrm{AmO}_{2}$ \\
\hline Heat source integration method & Pumped loop & Pumped loop & Pumped loop & $\begin{array}{c}\text { Pumped } \\
\text { loop }\end{array}$ & $\begin{array}{c}\text { Pumped } \\
\text { loop }\end{array}$ & $\begin{array}{c}\text { Pumped } \\
\text { loop }\end{array}$ \\
\hline Mission duration, $\mathrm{yr}$ & 10 & 10 & 10 & 10 & 10 & 10 \\
\hline Stirling hot end temp, ${ }^{\circ} \mathrm{C}$ & 1113 & 1113 & 1113 & 1113 & 1113 & 1113 \\
\hline Stirling cold end temp, ${ }^{\circ} \mathrm{C}$ & 360 & 360 & 360 & 360 & 360 & 360 \\
\hline Temperature ratio & 3.09 & 3.09 & 3.09 & 3.09 & 3.09 & 3.09 \\
\hline BOM heat, $\mathrm{W}$ & 3000 & 6000 & 15000 & 3016 & 5975 & 14965 \\
\hline AC output, W & 1075 & 2151 & 5376 & 1075 & 2151 & 5376 \\
\hline PC\&C power, $\mathrm{W}$ & 23 & 38 & 81 & 23 & 38 & 81 \\
\hline BOM DC power-nominal, $\mathrm{W}$ & 1000 & 2000 & 5000 & 1000 & 2000 & 5000 \\
\hline EOM DC power-nominal, $\mathrm{W}$ & 924 & 1848 & 4616 & 985 & 1971 & 4926 \\
\hline BOM daytime power (est.), W & 931 & 1862 & 4650 & 931 & 1862 & 4652 \\
\hline BOM nightime power (est.), W & 1035 & 2070 & 5170 & 1034 & 2069 & 5173 \\
\hline No. GPHS modules & 12 & 24 & 60 & 53 & 105 & 263 \\
\hline System mass, kg & 130 & 231 & 540 & 264 & 492 & 1173 \\
\hline Specific power, W/kg & 8.3 & 9.3 & 10.0 & 4.1 & 4.4 & 4.6 \\
\hline BOM efficiency, percent & $33 \%$ & $33 \%$ & $33 \%$ & $33 \%$ & $33 \%$ & $33 \%$ \\
\hline
\end{tabular}




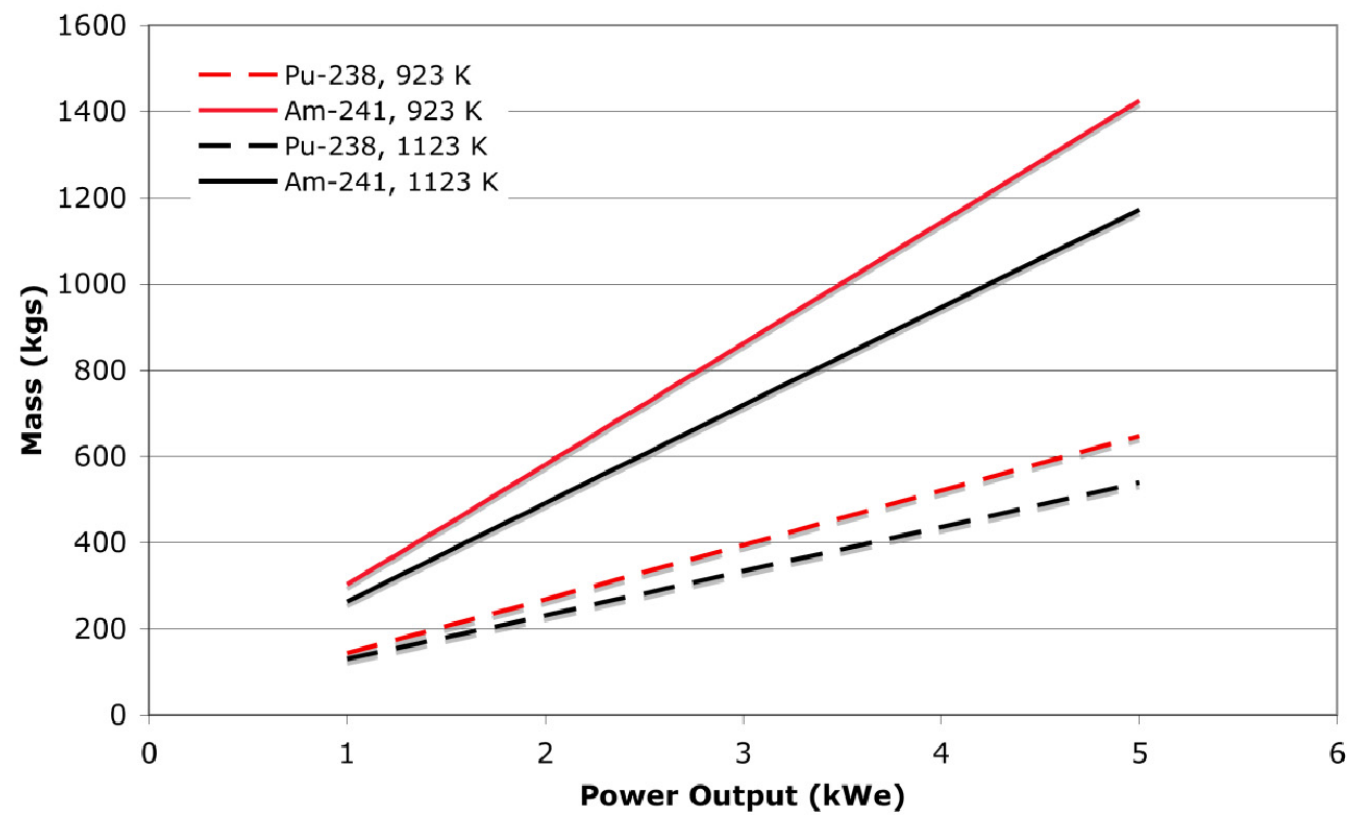

Figure 29.-Mass as a function of power level for 923 and $1123 \mathrm{~K} \mathrm{Pu}-238$ and Am-241 systems.

\section{Conclusions}

Substitution of Am-241 for Pu-238 into GPHS modules produces systems, which are either heavier for the same power or produces less power with the same GPHS count. Because of the very long half-life of Am-241 power output is nearly constant over the mission times considered here. Direct replacement of the Pu-238-based ASRG with Am-241 dropped power output from 164 to $29 \mathrm{~W}$ BOM and 148/28 W EOL dc power output, respectively. Sr-90 was also considered as another isotope option and provided $20 \mathrm{~W}$ BOM but because of its much shorter half-life provided only $14 \mathrm{~W}$ EOM when placed into an ASRG.

Two control strategies were considered for the ASRG with the various isotopes. For the Am-241 and $\mathrm{Pu}-238$, both appear reasonable for control of the ASRG. Power production is better using the constant heater head temperature control for both options; however, with the very long half-life of the Am-241 very small differences between the strategies is seen.

As power levels grow, pumped liquid $\mathrm{NaK}$ on the hot side and pumped water on the cold side of the Stirling were used for heat transport. A recently developed low temperature (923 K), 1-kWe Stirling convertor was modeled along with a higher temperature future convertor $(1123 \mathrm{~K})$. Heater head temperature improvements led to an approximately 10 percent reduction in system mass at $1 \mathrm{kWe}$ and 20 percent and $5 \mathrm{kWe}$. Pu-238 systems are approximately one-half the mass of their Am-241 counterparts with the mass differences growing slowly as power level increases.

Am-241 appears to be an isotopic candidate worth further consideration. When specific power is most important to a mission designer, $\mathrm{Pu}-238$ will be the clear choice. When isotopic availability is of prime concern and mass a smaller driver, Am-241 systems offer an attractive alternative. 


\section{References}

1. Pantano, D.R., Hill, D.H. "Thermal Analysis of Step 2 GPHS for Next Generation Radioisotope Power Source Missions," STAIF 2005.

2. Or, C.T., Carpenter R.T., "Steady State Temperature Predictions for General Purpose Heat Source in Various Environments," Proceedings of the 33rd Intersociety Engineering Conference on Energy Conversion, IECEC-98-227, Colorado Springs, CO (1998).

3. Or, C.T., Carpenter R.T., "Steady State Temperature Predictions for General Purpose Heat Source in Various Environments," Proceedings of the 33rd Intersociety Engineering Conference on Energy Conversion, IECEC-98-227, Colorado Springs, CO (1998).

4. http://www.ne.doe.gov/space/neSpace2g.html

5. Or, C.T., Carpenter R.T., "Steady State Temperature Predictions for General Purpose Heat Source in Various Environments," Proceedings of the 33rd Intersociety Engineering Conference on Energy Conversion, IECEC-98-227, Colorado Springs, CO (1998).

6. http://www.ne.doe.gov/space/neSpace2g.html

7. Department of Energy, Draft Environmental Impact statement for the proposed Consolidation of Nuclear Operations Related to Production of Radioisotopic Power Systems, DOE/EIS-0373D, p. 19.

8. R.C. O'Brien, et al., "Safe Radioisotope Thermoelectric Generators and Heat Sources for Space Applications," Journal of Nuclear Materials, Issue 377 (2008) pp. 506-521.

9. R.C. O'Brien, et al., "Safe Radioisotope Thermoelectric Generators and Heat Sources for Space Applications," Journal of Nuclear Materials, Issue 377 (2008) pp. 506-521.

10. Wood, G., Carroll, C., Matejczyk, D., Soendker, E., Penswick, L.B., “Advanced Stirling Convertor Update," STAIF 2006.

11. Schmitz, P., Penswick, L.B., Shaltens, R., "Stirling Isotope Power Systems for Stationary and Mobile Lunar Applications," 4th IECEC, San Diego, CA, 2006.

12. Wood, G., Carroll, C., Matejczyk, D., Soendker, E., Penswick, L.B., “Advanced Stirling Convertor Update," STAIF 2006.

13. ibid.

14. Schmitz, P., Penswick, L.B., Shaltens, R., "Stirling Isotope Power Systems for Stationary and Mobile Lunar Applications," 4th IECEC, San Diego, CA, 2006.

15. Schmitz, P., Penswick, L.B., Shaltens, R., "Modular GPHS-Stirling Power System for Lunar Habitation Module," 3rd IECEC, San Francisco, CA, 2005.

16. Bien, D.D. Guentert, D.C., "A Method for Reducing the Equivalent Sink Temperature of a Vertically Oriented Radiator on the Lunar Surface," NASA TM X-1729, NASA Lewis Research Center, Cleveland, OH, 1969.

17. Dallas, D., Diaguila, A.J., Saltsman, J.F., "Design Studies of the Effects of Orientation, Lunation, and Location on the Performance of Lunar Radiators," NASA TM X-1846, NASA Lewis Research Center, Cleveland, OH, 1971.

18. JPL presentation on lunar sink temperatures

19. http://esto.nasa.gov/conferences/nstc2007/papers/Shaltens_Richard_D2P1_NSTC-07-0138.pdf 


\begin{tabular}{|c|c|c|c|c|c|}
\hline \multicolumn{5}{|c|}{ REPORT DOCUMENTATION PAGE } & $\begin{array}{l}\text { Form Approved } \\
\text { OMB No. 0704-0188 }\end{array}$ \\
\hline \multicolumn{6}{|c|}{ 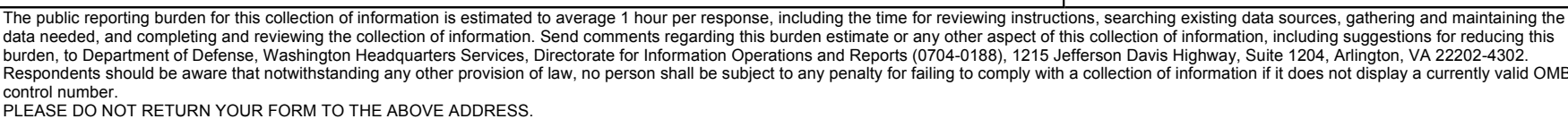 } \\
\hline \multicolumn{2}{|c|}{$\begin{array}{l}\text { 1. REPORT DATE (DD-MM-YYYY) } \\
01-07-2010\end{array}$} & \multicolumn{3}{|c|}{$\begin{array}{l}\text { 2. REPORT TYPE } \\
\text { Technical Memorandum }\end{array}$} & 3. DATES COVERED (From - To) \\
\hline \multirow{3}{*}{\multicolumn{5}{|c|}{$\begin{array}{l}\text { 4. TITLE AND SUBTITLE } \\
\text { Lunar Surface Stirling Power Systems Using Isotope Heat Sources }\end{array}$}} & 5a. CONTRACT NUMBER \\
\hline & & & & & 5b. GRANT NUMBER \\
\hline & & & & & 5c. PROGRAM ELEMENT NUMBER \\
\hline \multirow{3}{*}{\multicolumn{5}{|c|}{$\begin{array}{l}\text { 6. AUTHOR(S) } \\
\text { Schmitz, Paul, C.; Penswick, L., Barry; Shaltens, Richard, K. }\end{array}$}} & 5d. PROJECT NUMBER \\
\hline & & & & & 5e. TASK NUMBER \\
\hline & & & & & $\begin{array}{l}\text { 5f. WORK UNIT NUMBER } \\
\text { WBS } 138494.04 .01 .01\end{array}$ \\
\hline \multicolumn{5}{|c|}{$\begin{array}{l}\text { 7. PERFORMING ORGANIZATION NAME(S) AND ADDRESS(ES) } \\
\text { National Aeronautics and Space Administration } \\
\text { John H. Glenn Research Center at Lewis Field } \\
\text { Cleveland, Ohio 44135-3191 }\end{array}$} & $\begin{array}{l}\text { 8. PERFORMING ORGANIZATION } \\
\text { REPORT NUMBER } \\
\text { E-17288 }\end{array}$ \\
\hline \multirow{2}{*}{\multicolumn{5}{|c|}{$\begin{array}{l}\text { 9. SPONSORING/MONITORING AGENCY NAME(S) AND ADDRESS(ES) } \\
\text { National Aeronautics and Space Administration } \\
\text { Washington, DC 20546-0001 }\end{array}$}} & $\begin{array}{l}\text { 10. SPONSORING/MONITOR'S } \\
\text { ACRONYM(S) } \\
\text { NASA }\end{array}$ \\
\hline & & & & & $\begin{array}{l}\text { 11. SPONSORING/MONITORING } \\
\text { REPORT NUMBER } \\
\text { NASA/TM-2010-216352 }\end{array}$ \\
\hline \multicolumn{6}{|c|}{$\begin{array}{l}\text { 12. DISTRIBUTION/AVAILABILITY STATEMENT } \\
\text { Unclassified-Unlimited } \\
\text { Subject Category: } 20 \\
\text { Available electronically at http://gltrs.grc.nasa.gov } \\
\text { This publication is available from the NASA Center for AeroSpace Information, 443-757-5802 }\end{array}$} \\
\hline \multicolumn{6}{|c|}{ 13. SUPPLEMENTARY NOTES } \\
\hline \multicolumn{6}{|c|}{$\begin{array}{l}\text { 14. ABSTRACT } \\
\text { For many years, NASA has used the } \alpha \text { decay of plutonium-238 (Pu-238) (in the form of the General Purpose Heat Source (GPHS)) as a heat } \\
\text { source for Radioisotope Thermoelectric Generators (RTGs), which have provided electrical power for many NASA missions. While RTGs } \\
\text { have an impressive reliability record for the missions in which they have been used, their relatively low thermal to electric conversion } \\
\text { efficiency and the scarcity of plutonium-238 (Pu- } 238) \text { has led NASA to consider other power conversion technologies. NASA is considering } \\
\text { returning both robotic and human missions to the lunar surface and, because of the long lunar nights (14.75 Earth days), isotope power } \\
\text { systems are an attractive candidate to generate electrical power. NASA is currently developing the Advanced Stirling Radioisotope } \\
\text { Generator (ASRG) as a candidate higher efficiency power system that produces greater than } 160 \mathrm{~W} \text { with two GPHS modules at the } \\
\text { beginning of life (BOL) ( } 32 \% \text { efficiency). The ASRG uses the same Pu- } 238 \text { GPHS modules, which are used in RTG, but by coupling them } \\
\text { to a Stirling convertor provides a four-fold reduction in the number of GPHS modules. This study considers the use of americium-241 (Am- } \\
241) \text { as a substitute for the Pu- } 238 \text { in Stirling- convertor-based Radioisotope Power Systems (RPS) for power levels from tens of watts to } 5 \\
\text { kWe. The Am-241 is used as a substitute for the Pu-238 in GPHS modules. Depending on power level, different Stirling heat input and } \\
\text { removal systems are modeled. It was found that substituting Am-241 GPHS modules into the ASRG reduces power output by about one- } \\
\text { fifth while maintaining approximately the same system mass. In order to obtain the nominal } 160 \mathrm{~W} \text { of electrical output of the Pu- } 238 \text { ASRG } \\
\text { requires } 10 \text { Am-241 GPHS modules. Higher power systems require changing from conductive coupling heat input and removal from the } \\
\text { Stirling convertor to either pumped loops or heat pipes. Liquid metal pumped loops are considered as the primary heat transportation on the } \\
\text { hot end and water pumped loop/heat pipe radiator is considered for the heat rejection side for power levels above } 1 \mathrm{kWe.}\end{array}$} \\
\hline \multicolumn{6}{|c|}{$\begin{array}{l}\text { 15. SUBJECT TERMS } \\
\text { Radioisotope Thermoelectric Generator (RTG); Advanced Stirling Radioisotope Generator (ASRG); General Purpose Heat Source } \\
\text { (GPHS) }\end{array}$} \\
\hline \multicolumn{3}{|c|}{ 16. SECURITY CLASSIFICATION OF: } & $\begin{array}{l}\text { 17. LIMITATION OF } \\
\text { ABSTRACT }\end{array}$ & $\begin{array}{l}\text { 18. NUMBER } \\
\text { OF }\end{array}$ & $\begin{array}{l}\text { 19a. NAME OF RESPONSIBLE PERSON } \\
\text { STI Help Desk (email:help@ } \text { sti.nasa.gov) }\end{array}$ \\
\hline $\begin{array}{l}\text { a. REPORT } \\
\text { U }\end{array}$ & $\begin{array}{l}\text { b. ABSTRACT } \\
\text { U }\end{array}$ & $\begin{array}{l}\text { c. THIS } \\
\text { PAGE } \\
\text { U }\end{array}$ & UU & $\begin{array}{l}\text { PAGES } \\
33\end{array}$ & $\begin{array}{l}\text { 19b. TELEPHONE NUMBER (include area code) } \\
443-757-5802\end{array}$ \\
\hline
\end{tabular}



